University of Rhode Island

DigitalCommons@URI

Open Access Master's Theses

1972

\title{
Preparation of Fish Protein Concentrate (FPC) from Shark
}

Moshin Ali

University of Rhode Island

Follow this and additional works at: https://digitalcommons.uri.edu/theses

\section{Recommended Citation}

Ali, Moshin, "Preparation of Fish Protein Concentrate (FPC) from Shark" (1972). Open Access Master's Theses. Paper 979.

https://digitalcommons.uri.edu/theses/979

This Thesis is brought to you for free and open access by DigitalCommons@URI. It has been accepted for inclusion in Open Access Master's Theses by an authorized administrator of DigitalCommons@URI. For more information, please contact digitalcommons-group@uri.edu. 


\section{PREPARATION OF FISH PROTEIN CONCENTRATE}

(FPC) FROM SHARK

By

MD. MOHSIN ALI

A THESIS SUBMITTED IN PARTIAL FULFILLMENT OF THE REQUIREMENTS FOR THE DEGREE OF

MASTER OF SCIENCE

IN

FOOD AND RESOURCE CHEMISTRY

UNIVERSITY OF RHODE ISLAND

1972 
MASTER OF SCIENCE THESIS

OF

MD. MOHSIN ALI

Approved:

Thesis Committee:

Chairman:

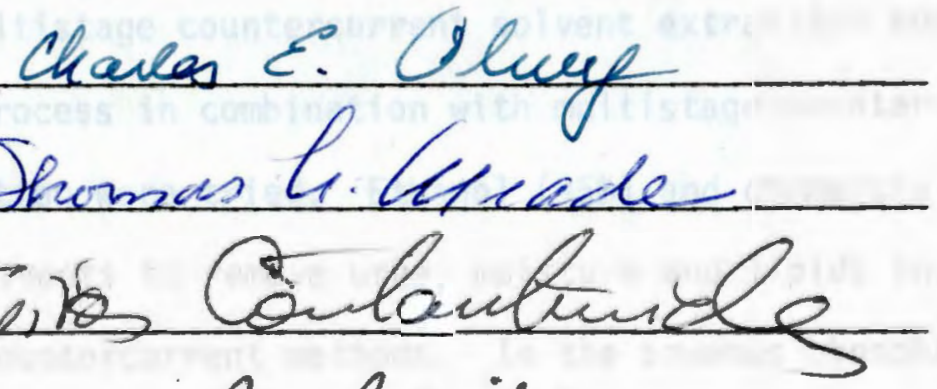

Blows A.huchel

Dean of the Graduate School

UNIVERSITY OF RHODE ISLAND

1972 


\section{ABSTRACT}

The meat of sharks and other members of the family Elasmobranchii contains urea. Urease, present in fish muscle or released by microbes grown during storage, catalyzes the decomposition of urea to ammonia, which is responsible for off-flavor and odor in products from fish containing urea. Therefore, it is necessary to remove urea in the preparation of FPC (fish protein concentrate) from shark meat, if the FPC is to be utilized as a highly nutritive animal protein supplement in food to combat human malnutrition in developing and underdeveloped countries.

For the production of urea-free FPC, multistage cross-current solvent extraction, multistage countercurrent solvent extraction and an aqueous phosphate process in combination with multistage countercurrent solvent extraction were tried. Ethanol (95\%) and commercial hexane were used as solvents to remove urea, moisture and lipids in the crosscurrent and countercurrent methods. In the aqueous phosphate process, hexametaphosphate at $\mathrm{pH} 4.0$ was used to precipitate protein from an aqueous medium while urea was removed with the water phase. Subsequent solvent extraction reduced the moisture and lipid levels to below the FDA limits of $10 \%$ and $0.5 \%$, respectively.

In all stages the solvent was added in the ratio of one $\mathrm{ml}$ per gram of ground raw fish. Starting with shark meat containing $1.1 \%$ urea and 13.4\% lipids, the urea and lipid levels in the FPC were 0.16 and $0.61 \%$, respectively, following countercurrent solvent extraction 
using three ethanol stages followed by three hexane stages with 15 minute extraction periods. Six crosscurrent ethanol extractions with 60 minute extraction periods reduced the urea level in the FPC to a trace, while the 1ipid was $0.41 \%$. The FPC produced by these methods was white or light cream colored with no or slight amine and fishy odor and good functional properties.

The FPC produced by the aqueous phosphate process followed by countercurrent solvent extraction was better in color, odor, flavor and texture than FPC produced by the solvent extraction alone. The urea and lipid levels in the FPC were 0.07 and $0.56 \%$, respectively. 


\section{ACKNOWLEDGEMENTS}

This author is grateful to and thanks Dr. Charles E. 01ney of the Department of Food and Resource Chemistry for his technical assistance, guidance, valuable counsel, and for his suggestions on the preparation and review of the manuscript. I also thank him for consoling me during my days of sorrow and hardship. I had to pass during the study of this problem due to the different calamities in my homeland.

Appreciation is rendered to Dr. Thomas L. Meade for his suggestions and review of this manuscript.

My hearty thanks to Dr. Spiros M. Constantinides for his valuable advice and review of this manuscript.

Profound thanks to Dr. M. Youssouf A1i, Director of Fisheries, Peoples' Republic of Bangladesh for nominating me for higher training, and the United States Agency for International Development for offering me assistance with this program.

And last, but not the least, sincere thanks to my wife, Hosne Ara and my father-in-law for looking after my family in those dark days of East Bengal (Bangladesh). 
TABLE OF CONTENTS

Page

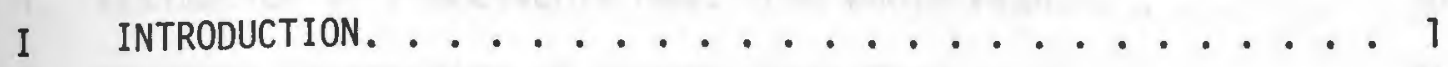

II REVIEW OF LITERATURE. ................ 4

FPC from Teleostei.............. 4

FPC from Elasmobranchii . . . . . . . . . 11

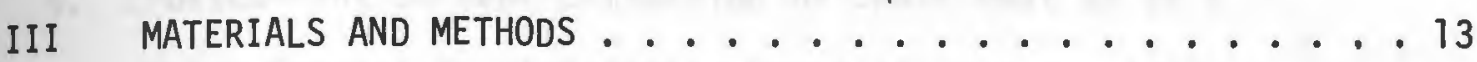

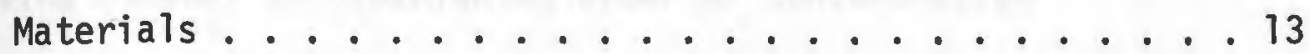

Methods of Processing ............. 14

Analytical Methods.............. . 17

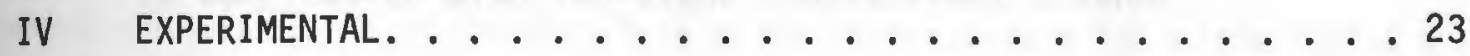

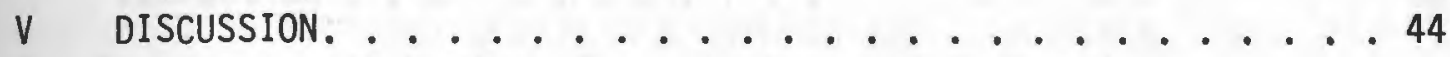

VI CONCLUSIONS AND RECOMMENDATIONS ........... 62

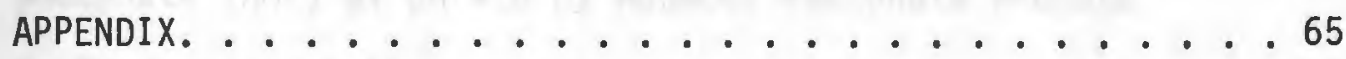

REFERENCES. ..................... 67 


\section{LIST OF TABLES}

Table

1. Estimation of Processable Meat from Whole Fish. . . . . . 30

2. Chemical Composition of Ground Shark Meat . . . . . . . . 31

3. Effect of Temperature on the Solvent Extraction of Urea from Shark Meat. ............. 32

4. Crosscurrent Solvent Extraction of Shark 'Meat at $65 \mathrm{C}$ Using Ethanol in Diminishing Order of Concentration for First Stage................ 33

5. Effect of $\mathrm{pH}$ and Temperature in Aqueous Phosphate Process in Combination with Two-Stage Crosscurrent Ethanol

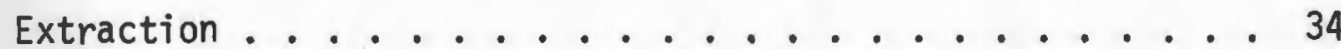

6. Treatment with Various Concentrations of Sodium Hexametaphosphate (HMP) at pH 4.0 by Aqueous Phosphate Process

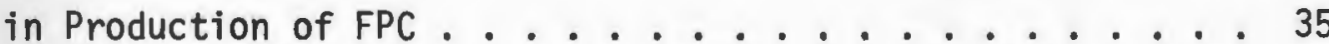

7. Comparison of FPC from Crosscurrent and Countercurrent Solvent Extraction of Shark. . . . . . . . . 36

8. Effect of Variation in Number of Stages in Countercurrent Extraction of Shark Meat for Production of FPC . . . . . 37

9. FPC Produced by Aqueous Phosphate Process with Variation in Number of Stages of Countercurrent Solvent Extraction . . 38

10. Keeping Quality of Ground Shark Meat in 95\% Ethanol at $28 \pm 2$ C. 
11. Effect of Varying Length of Extraction Period in

Production of FPC from Shark Meat by Crosscurrent

Solvent Extraction. ............. 40

12. The Sensory Evaluation and Functional Properties of

FPC from Shark. . . . . . . . . . . . 41

13. Proximate Composition of FPC Produced by bifferent

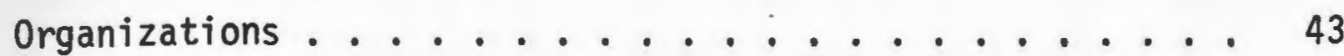




\section{LIST OF FIGURES}

Figure

Page

1. Schematic Diagram of 3-Stage Batch Crosscurrent

Solvent Extraction Process. . . . . . . . . 20

2. Schematic Diagram of 3-Stage Batch Countercurrent

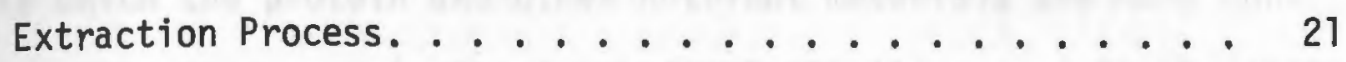

3. Schematic Diagram of Aqueous Phosphate Process. . . . . 22 


\section{INTRODUCTION}

Fish protein concentrate (FPC) is defined in various ways. One of these is "Fish protein concentrate is any low cost, stable, wholesome product of high nutritive quality, hygienically prepared from fish, in which the protein and other nutrient materials are more concentrated than they were in the fresh fish" (Stj1lings and Knobl, 1971). The characteristics of the products may range from tasteless, odorless, light-colored, flour-like materials to colored products having a slightly fishy taste and odor. This concentrated protein can be used as a supplement in human diets to combat protein malnutrition (Moorjani and Lahiry, 1970).

The population of the world is, perhaps, growing at a faster rate than the production of foods for them. Over and again, the protein foods are already in alarming deficiency in the underdeveloped and developing countries and even among some groups of people in the developed countries.

In most of the developed and developing countries, fishes like anchovies (Linson, 1966), cod (Fougere, 1962 and Pariser, 1963), haddock (Guttmann and Vandenheuve1, 1957), hake (Caiozzi et al., 1968), menhaden (Whaley and Moshy, 1965) and sardine (Brown and Miller, 1969) are used in the production of FPC. Very little attention is given to a fairly large family of fish, the Elasmobranchii. The Elasmobranchii is comprised of sharks, skates and rays. Among the smaller varieties of sharks, some are commonly known as dogfish. 
Three-quarters of the surface of the earth is covered with salt water. The vast area of tropical and sub-tropical salt waters like the Caribbean, the Gulf of Mexico, the Bay of Bengal, the Arabian Sea, the south coast of Australia and New Zealand and the west coast of the U.S.A. are heavily infested with sharks and other members of this family (Borgstrom, 1962). It has been reported that about 33 percent of the total catch of fish in the Bay of Bengal, is Elasmobranchi $i$ (Hussain, 1967) and 25 percent in the Arabian Sea off the coast of Karachi, Pakistan is shark (Mahdihassan, 1962). It has also been reported that as much as 30 percent of the total catch in the Gulf of Mexico and the Caribbean (Bullis, 1957) and about 20 percent in the Indian Ocean (Kataoka, 1958) is damaged by sharks.

The utilization of shark meat for FPC production may serve two distinct purposes: (1) provide high protein food for human and animal nutrition and (2) reduce the damage to the other valuable fish by sharks, thereby boosting the yield of protein food for the people. In addition, the production of protein food may be increased by feeding urea-free FPC from Elasmobranchii meat to monogastric animals such as poultry and swine (Osterhaug, 1961). For these purposes, sharks may be harvested judiciously to maintain the balance in the natural ecology and also to get maximum production of shark meat for protein foods.

Shark meat contains a relatively high amount of urea (Alverson and Stansby, 1963). The latter compound decomposes to ammonia and carbon dioxide by the action of urease, an enzyme present in Elasmobranchii 
muscle and can also be released by bacteria growing on the meat (Simidu and Oisi, 1952). Trimethylamine oxide (TMAO) is also present in Elasmobranchii meat (Groninger, 1959). This compound is reduced by enzymatic action in the fish muscle and by the microorganisms to trimethylamine (TMA). TMA has a very putrid fishy odor. Both ammonia and TMA evolved in the above-mentioned processes render off-flavor and tas te to shark meat and its products, particularly when the products are kept in storage for a considerable period at room temperature (250 $30 \mathrm{C})$. So removal of urea, TMAO and TMA is important.

The lipids present in shark meat are also responsible for offflavors on account of development of rancidity. The high moisture content helps the microbial spoilage of fish. As such, the U.S. Food and Drug Administration has set maximum levels of lipids and moisture in FPC at $0.5 \%$ and $10 \%$, respectively (Appendix $A$ ).

Processing of shark meat will help in preventing microbial spoilage and will minimize storage, handling and transportation costs. Thus, finding a suitable method for producing FPC by removing urea, lipids and moisture from shark meat is the objective of this investigation. 


\section{REVIEW OF LITERATURE \\ FPC from Teleostei}

The preparation of protein concentrate from fish, a highly perishable but an excellent nutritive commodity, is not a new but a very old idea. To save the nutritious meat of fish from complete spoilage, drying, salting and drying, smoking and making fish paste are still in use in the underdeveloped countries of the world. All these processes involve concentration of protein from fish. And the people use these products in their foods.

In ancient times, dry fish was not only used in human nutrition but also as fertilizer, after grinding, for increasing the productivity of the soil. Dried and ground fish known as fish-meal was used and even now is used in poultry and pet nutrition.

In the late nineteenth century, Waage in Norway prepared FPC with a good keeping quality for human consumption in the name of fish-meal (Bakken, 1961). In the process, fish fillets were chopped and dried in a high velocity air stream at a temperature of $40-60 \mathrm{C}$ to a moisture content of 5-6 percent. The product was then finely ground and sifted.

In 1936, the Norwegian Fish Powder Corporation produced fish-meal for human consumption (Bakken, 1961). The raw materials, mainly muscle from haddock and cod, were first cooked with live steam injected at a temperature of about $60 \mathrm{C}$. After cooking, the mass was pressed in order to remove the glue materials. The press cake was dried under reduced 
pressure at a temperature of about $40^{\circ} \mathrm{C}$. The dried cake was sifted to separate bones which were ground to powder and mixed with fish-meal.

In Iceland, in 1938, an attempt was made to prepare fish flour from skinned cod fillets under sanitary conditions. The fillets were dried in a steam-jacketed vacuum drier (Hannesson, 1962).

In 1937, attempts were made in South Africa to produce tasteless and odorless fish flour for enriching cereal products intended for human consumption (Dreosti, 1962).

Since the second world war much attention has been given in all scientifically developed and developing countries to the preparation of the FPC to meet the ever growing need of protein food, to cut the length of the food chain used in converting fish to animal protein consumable by humans (Roels, 1969) and particularly to combat the problem of protein malnutrition disease, kwashiorkor, in developing and underdeveloped countries (Srikantia and Gopalan, 1966).

For this purpose, various methods have been developed to prepare FPC for human consumption. These methods can be placed under three main divisions. These are: (A) physical methods, (B) solvent extraction methods and (C) hydrolysis of fish. The combination of any two of these methods or all of the three methods may increase the efficiency of the process.

A. Physical Methods On the basis of this method, FPC plants have been set up in Congo/Ruanda-Burundi, Ghana and Uganda (Roels, 1969). In those plants fresh fish is autoclaved, the cooked fish is pressed to 
remove fish solubles and lipids, and the press cake is dried, ground and packed in suitable sizes.

B. Solvent Extraction Methods These methods are widely used in the developed and developing countries like Canada, Chile, France, Germany, India, Japan, Mexico, Pakistan, Panama, Peru, Scandinavian countries, South Africa, The United Kingdom, The United States of America and Uruguay. The application of physical proces'ses such as raising the temperature, stirring, filtration, pressing, distillation, vacuum drying, etc., increases the efficiency of the process. Some of the processes developed for the manufacture of FPC in some of the above mentioned countries are reviewed below.

Canada Workers at the Halifax Technological Laboratory of the Fisheries Research Board of Canada developed a process of manufacturing FPC using isopropanol (IPA) as the solvent for extracting water and lipids from fish muscle. The process is known as the "Guttmann-Vandenheuve1Gunnarsson" process. They used cod fillets, whole cod, eviscerated cod, cod trimmings, haddock and hake as raw materials (Fougere, 1962). The process is briefly described here. The heads were removed and discarded, and the back bones and adhering muscles were ground in a meat chopper to quarter of an inch size. Equal weights of water and ground material were well mixed, acidified to $\mathrm{pH}$ 5.4-5.5 with polyphosphoric acid, and the acidified slurry was heated and stirred for 30 minutes at $65.5 \mathrm{C}$. The slurry was centrifuged in a basket centrifuge and washed with hot water until the effluent was clear. The slurry was mixed with 
0

twice its weight of IPA (86\%), heated to $82 \mathrm{C}$ for fifteen minutes and vacuum filtered. After a second solvent extraction and filtration, the extracted material was dried in an oven dryer at $37.5 \mathrm{C}$ for 24 hours. The resultant dry material was screened through 16 and 20 mesh screens to separate bones and skins from protein and each fraction was ground in a Rietz grinder using a 1/32 inch screen. The fish flour thus obtained was, for all practical purposes, white, tasteless and odorless. This method has been improved by Power (1962).

Chile Whole hake was washed, comminuted and mixed with isobutanol in the ratio of $1: 3$ ground fish:isobutanol $(w / w)$ with constant stirring for 30 minutes at room temperature and then at a temperature of 89.2 0

91 $\mathrm{C}$ for 4 hours. The extracted fish was then subjected to vacuum fi1tration. The fish cake thus obtained was washed twice with alcohol and finally it was filtered again. The FPC was dried at $60-65^{\circ} \mathrm{C}$ under reduced pressure to about 3-4 percent moisture (Hevia et al., 1971).

Germany This process was developed during World War II. Whole fish was ground and treated with $0.5 \%$ acetic acid with continuous stirring. The slurry was pressed and the press cake was extracted with ethanol. Following ethanol extraction, the press cake was hydrolyzed with alkali and filtered. The protein solution was neutralized with acetic acid and spray dried (Roels, 1969).

India FPC was produced from whole fish or eviscerated fish using ethanol (absolute or 96\%) as solvent. The extractions were carried out in 
six to seven stages at the boiling point of ethanol for a period of 15-20 minutes in each stage. The products were uniform from batch to batch. They were fine, non-gritty powders with light color and bland flavor (Moorjani and Lahiry, 1970).

Peru A process has been developed in this country to produce FPC from hake. The fish is first dried to a maximum moisture content of $8 \%$ by heat. The semi-dehydrated fish is sealed in an 'extractor and a vacuum is created, which opens the pores and cells of the fish material and exposes it more freely to hexane vapor which is used as solvent. The vaporized solvent removes all but less than 1 percent of the fat. Because of the low fat content, further deodorization is not necessary. The product is sterilized in the extractor (Philips, 1969).

Sweden "Astra Nutrition" produces FPC from herring using IPA as solvent. Fish is cooked with constant heat and stirring. The cooked fish is pressed and the pressed cake is subjected to successive extraction with solvent to reduce the fat content to the desired level. This defatted material is then desolventized and ground to FPC (Bakken, 1962; Roels, 1969 ; Lawler, 1970).

The United Kingdom Cavanagh and Inman obtained British patent \#1,009,338 for the preparation of FPC by extracting fish with solvent mixtures of acetone, ethyl acetate and ethanol (Roels, 1969).

United States of America Various organizations have developed different processes in this country of which the following are important: 
(1) Viobin Process In this process the fish is comminuted and the comminuted fish is dehydrated by an azeotropic distillation of water with ethylenedichloride. The dehydrated fish is then treated with more solvent to remove the lipids. Finally it is extracted with alcohol to get colorless and odorless FPC after grinding (Levin, 1959). The Viobin Corporation at Monticello, Illinois, the Alpine Marine Protein Industries, Inc. at New Bedford, Massachusetts, and the Cape Flattery Co. at Seattle, Washington, use the "Viobin Process" to produce FPC in industrial scale.

(2) The Bureau of Commercial Fisheries Currently known as the National Marine Fisheries Service, the Bureau has developed two methods of preparation of FPC.

(a) IPA Process Essentially this was first developed in Canada (Guttmann-Vandenheuve1-Gunnarsson Process) and further developed in the U.S.A. This process utilizes a successive series of extractions with azeotropic IPA moving countercurrent to the product to simultaneously dehydrate and defat comminuted fish. Residual solvent is then removed by either vacuum or atmospheric drying (BCF, 1966). This process is utilized to manufacture FPC by Star-Kist, Aberdeen, Washington.

\section{(b) Aqueous Phosphate Process (Spinelli and Koury, 1970;}

Spinelli et a1., 1971). In this process, fish is comminuted by grinding or by a "Yanagiya flesh separator" which also skins and debones the fish. The comminuted fish is mixed with an equal part of water and sufficient acid ( $H$ SO ) is added to lower the $\mathrm{pH}$ to 5.7. The mixture is then rapidly heated to $70^{\circ}-80^{\circ} \mathrm{C}$ to inactivate the proteolytic enzymes. 
Immediately after heating, sodium hexametaphosphate ( $1 \%$ based on weight of wet fish) in $5 \%$ aqueous solution is added to the acidified fishwater mixture. The pH of the slurry is then lowered to about 3.8-4.0 with $1 \mathrm{MH} \mathrm{SO}$. The slurry is centrifuged, yielding an aqueous-oil phase and a complexed solid fraction. The solid fraction is twice suspended in equal parts of water to remove other non-protein water soluble materials. The solid is then extracted twice with azeotropic IPA to remove water and residual oils. This is a new process. No industry has yet been developed on the basis of this process.

C. Hydrolytic Methods (The hydrolytic process for the preparation of FPC.) Two types of hydrolysis have so far been tried. These are (1) chemical hydrolysis and (2) enzymatic hydrolysis.

(1) Chemical Hydrolysis In this process whole fish is hydrolyzed chemically. The hydrolyzed product is filtered through a filter press to separate undissolved bones, skin and scale from protein solution. The filtrate is concentrated to about $50 \%$ solid and spray dried (Roels, 1969).

(2) Enzymatic Hydrolysis The process is identical to the chemical hydrolysis process, except that a proteolytic enzyme or a suitable microorganism is used in place of chemicals and the $\mathrm{pH}$, temperature and concentration of the reacting media are controlled to achieve maximum activity of the enzymes. Rohn and Haas Company in Philadelphia, Pennsylvania in the United States (Roels, 1969) and the Tokai Regional Fisheries Research Laboratory in Japan (Onishi and Higashi, 1968) have developed methods to produce FPC by using proteolytic enzymes. 


\section{FPC from Elasmobranchii}

In most cases anchovies, cod, ling-cod, hake, herring, haddock, pollack, sardine, whiting and similar species of fish have been used to manufacture FPC. Hardly any attempt has been made to utilize the species under the family Elasmobranchii in the scientifically developed countries. However, some attention has been given in the developing countries like India, Mexico and Pakistan to the preparation of FPC from elasmobranchs.

India In this country, Revankar et al., (1965) prepared FPC from shark. The shark meat was ground, cooked and pressed. The press cake was soaked in $1.0 \%$ acetic acid overnight. The acidified slurry was then filtered and the cake was extracted with $95 \%$ ethanol to remove oil and water.

Mexico A process has been worked out to prepare FPC from shark meat. In this process, sharks are eviscerated, bled and washed thoroughly with water. The meat is cut in $1 / 4$ inch cubes, extracted with IPA at the temperature of $20^{\circ}-30^{\circ} \mathrm{C}$ for a period of 50 minutes and filtered. A second extraction is carried out for 90 minutes at $75^{\circ} \mathrm{C}$ followed by a third extraction at $75^{\circ} \mathrm{C}$ for 75 minutes (Du Solier MacGregor and Cavazo, 1969).

Pakistan Abdul Haq (1960) prepared FPC from shark meat. To remove urea, minced shark meat was cooked with soy bean meal at $40^{\circ} \mathrm{C}$. The mixture was dried at $50^{\circ}-55^{\circ} \mathrm{C}$ to $10 \%$ moisture content, powdered, and extracted 
with solvent oil b.p. $60^{\circ}-120^{\circ} \mathrm{C}$ for 3 hours at $65^{\circ} \mathrm{C}$ in the ratio $1: 6$, $\mathrm{wt} / \mathrm{vol}$. The oil was removed, the $\mathrm{pH}$ of the mixture was raised to 8.0 with $6 \%$ ethanolic $\mathrm{NaOH}$ and the mixture was refluxed for 3 hours at $65^{\circ} \mathrm{C}$. After reflux the product was neutralized with hydrochloric acid and the supernatant liquid was decanted off. The residue was filtered and shaken with petroleum ether in the ratio of $1: 3$. The product obtained after decantation was kept at $50 \mathrm{C}$ for desplventization. 


\section{MATERIALS AND METHODS}

\section{Materials}

Two members of the family Elasmobranchii were used in the study. Most of the work was done with spiny dogfish, Squalus acanthias, while sand shark, Carcharias taurus was used as the raw material for two experiments. These two species were readily avai fable from the fishermen at Point Judith, Rhode Island, U.S.A. The spiny dogfish was collected in two batches, one in the last week of March and the second in the last week of April, 1971. The batch of sand shark was collected in the first half of September, 1971.

One consignment of spiny dogfish and the consignment of sand shark were washed to remove loose dirt and processed by skinning, beheading, gutting and filleting on the date of their receipt. The flesh, with cartilages, from one batch of dogfish was minced by a hand-driven meat 0 grinder and stored in a deep-freeze at $-20 \mathrm{~F}$ for further processing to FPC. The flesh from sand shark, wi thout cartilages, was ground in a motor driven "Hobart Food Cutter". Half the ground flesh from the sand shark was divided into four portions for studying the preservation of ground meat with $95 \%$ ethanol. The other half of ground flesh was used to study the effect of different concentrations of sodium hexataphosphate in FPC production.

The second consignment of spiny dogfish was cleaned with tap water and put into the deep-freeze over the weekend. The fish were partially thawed and processed like the dogfish described above, except that the 
flesh, without cartilage, was ground in the motor driven food chopper. The minced flesh was preserved in the deep-freeze for future use.

\section{Methods}

\section{A. Methods of Processing}

(1) Crosscurrent Solvent Extraction The principle for batch crosscurrent solvent extraction of fish muscle is shown in Figure 1. Essentially it consists of extracting a material with successive portions of fresh solvent. Two types of solvents were used separately for extraction. The solvents were $95 \%$ ethanol (b.p. $78.3^{\circ} \mathrm{C}$ ) and commercial hexane (b.p. $65^{\circ}-69^{\circ} \mathrm{C}$ ). Two hundred grams of ground fish was well mixed with $200 \mathrm{ml}$ of $95 \%$ ethanol and heated to $65-5 \mathrm{C}$ with stirring. When the temperature was attained, the slurry was held at that temperature for 15 minutes with occasional stirring. The hot mixture was subjected to filtration $(F)$. The filtrate is termed miscella $(M)$, and the residue is termed cake (C). And the whole process from mixing of flesh with solvent through the filtration operation is called the first stage.

The cake (C-1) was then mixed with another $200 \mathrm{ml} 95 \%$ ethanol, $0+0$

heated to $65-5 \mathrm{C}$, and held at that temperature for 15 minutes with stirring. The mixture was filtered. The filtrate is termed miscella $M-2$, the residue is cake $C-2$ and the whole process is the second stage. In a similar fashion, the cake could be extracted with additional batches of solvent. After completing extraction with selected solvents, the fish cake was desolventized and ground in a Wiley Inter- 
mediate Mill with 60 mesh screen. Solvents and oils are to be recovered from miscellas.

(2) Countercurrent Solvent Extraction The batch countercurrent solvent extraction principle is shown in figure 2 . In a process where three successive extractions with a solvent are needed, the first, second and third extractions are termed as first, second and third stage, respectively. Each of the vertical columnis represents a stage. One batch of fish processed through three stages is termed a run. In three-stage countercurrent processing, true countercurrent extraction does not start until after the third run.

After establishment of true countercurrent process extraction, a batch of raw material is extracted with the miscella from the second extraction of the previous run. The mixture is held at $65^{\circ} \pm 5^{\circ} \mathrm{C}$ for 15 minutes with stirring and then filtered. The filtrate is miscella $M-1$ and residue is wet cake $C-1$. The wet cake is extracted with miscella M-3 from the previous run at a temperature of $65^{\circ} \pm 5^{\circ} \mathrm{C}$ for 15 minutes. The mixture is filtered. The filtrate is second miscella $M-2$, and the wet cake $C-2$ is extracted with fresh solvent as described for the previous two stages. The mixture is filtered. The filtrate is miscella $\mathrm{M}-3$, and the wet cake $\mathrm{C}-3$ is subjected to further countercurrent extraction, or desolventized by air drying and ground to FPC. The first miscellas $(M-1)$ would be sent to solvent recovery units to recover lipids and respective solvents. 
In Figure 2, CA-1, CA-2 and $C A-3$ are wet cakes and $M A-1, M A-2$ and MA-3 are miscellas in run $A$ of stages 1,2 and 3 , respectively. $C B-1$, $C B-2$, and $C B-3$ are wet cakes in run $B ; C C-1, C C-2$, and $C C-3$ are wet cakes in run $C$. $M B-1, M B-2$, and $M B-3$ are the miscellas from run $B$ and $M C-1, M C-2$, and $M C-3$ are the miscellas from run $C$.

(3) Aqueous Phosphate Process The process is summarized in Figure 3. Ground fish was mixed with $1 \%$ hexametaphospháte (HMP) solution ( $1 \mathrm{~g}$ HMP per $100 \mathrm{ml} ; 100 \mathrm{ml}$ per $100 \mathrm{~g}$ fish). The $\mathrm{pH}$ of the mixture, initially 6.8 , was lowered to $3.6 \pm 0.2$ by adding $6 \underline{\mathrm{N}} \mathrm{H}$ SO with constant stirring. The acidulated mixture was heated to $65 \pm 5^{\circ} \mathrm{C}$ and held at that temperature for 15 minutes. The $\mathrm{pH}$ of the mixture was checked after the heating period by cooling a portion of the mixture to room temperature. In most cases the $\mathrm{pH}$ was found to be $4.0 \pm 0.1$ or it was adjusted to that $\mathrm{pH}$ by adding the required quantity of $6 \mathrm{~N} H \mathrm{SO}$. This was done to precipitate out the maximum amount of phosphateprotein complex. The mixture was centrifuged for 10 minutes at 20,000 $x g$ in a bucket centrifuge and the supernatant liquid was decanted off. The solid was washed by mixing with water once and centrifuged as before. The supernatant liquid was decanted off and the sediment was squeezed to expel more liquid from the cake. The cake was subjected to crosscurrent or countercurrent solvent extraction using ethanol and hexane separately. After the final extraction and desolventization, the products were ground in a Wiley Intermediate Mill with 60 mesh screen. 
In Figures 1-3, solvent and oil recovery steps are indicated. These were not studied in this investigation, although they would be critical steps in any economically sound FPC process.

\section{B. Analytical Methods}

The composition of raw frozen fish muscle and samples of FPC in respect to urea, protein, lipid, total volatiles (T.V.) and ash content and the water and oil holding properties of FPC were determined by the following methods:

(1) Urea Urea was estimated colorimetrically using the method described by the Association of Official Analytical Chemists (AOAC, 1970, Section 7.029). The reagent used for this purpose was DMAB ( $p-$ dimethylaminobenzaldehyde, Eastman 95). DMAB reacts with urea to form a complex which absorbs light at $420 \mathrm{~nm}$.

Urea was extracted from fish muscle $(1 \mathrm{~g})$ and samples of FPC (5gms) by shaking for 30 minutes with $80 \mathrm{ml}$ distilled water, $5 \mathrm{ml}$ of $10.6 \%$ $\mathrm{K} \mathrm{Fe}(\mathrm{CN})-.3 \mathrm{H} 0,5 \mathrm{ml}$ of $22 \% \mathrm{Zn}(\mathrm{OAC}) .2 \mathrm{H} 0$ and $1 \mathrm{~g}$ charcoal. The mix$\begin{array}{lll}4 & 6 & 2\end{array} 2$ ture was filtered through a Buchner funnel. The residue was washed with 5-10 $\mathrm{ml}$ of distilled water and the total volume was made to 100 $\mathrm{ml}$ by adding distilled water. For developing color, $5 \mathrm{ml}$ aliquots of the extract were mixed with $5 \mathrm{ml}$ of DMAB reagent. The optical density (0.D.) of this colored solution was measured in a Beckman Model DU Dectrophotometer. The urea concentration in the sample was calculated from the observed 0.D. using a standard curve.

(2) Protein Protein was determined by the macro-Kjeldahl method as described by the AOAC (1970, Section 7.016). 
(3) Lipid Lipid was estimated by the semimicro method of Ambrose et a1. (1968). Five gms of sample, ground freshly frozen raw fish or FPC, was blended with $30 \mathrm{ml}$ chloroform, $20 \mathrm{ml}$ methanol and $7 \mathrm{ml}$ water for 2 minutes. Another $10 \mathrm{ml}$ chloroform was added and the mixture was blended for another 30 seconds. The entire contents of the blender were transferred in a $250 \mathrm{ml}$ beaker containing 4 gms anhydrous sodium sulfate and 4 gms hyflo-supercel.

The contents of the beaker were thoroughly mixed and filtered. The filtrate was transferred into a $100 \mathrm{ml}$ graduated cylinder and the residue was blended with $40 \mathrm{ml}$ chloroform and filtered. The filtrate was added to the original filtrate in the cylinder and $10 \mathrm{ml}$ water was added to the mixture. The mixture was shaken well and allowed to settle for at least one hour with occasional slow stirring at the cylinder wall to remove adhering water. The methanol-water was removed by siphoning and a $25 \mathrm{ml}$ aliquot of the chloroform layer was evaporated in a tared flask under reduced pressure. The residue in the flask was dried at $100^{\circ} \mathrm{C}$ in an oven for 30 minutes. The flask was cooled to the room temperature and weighed. From the gain in weight of the flask, the percentage of lipid was calculated.

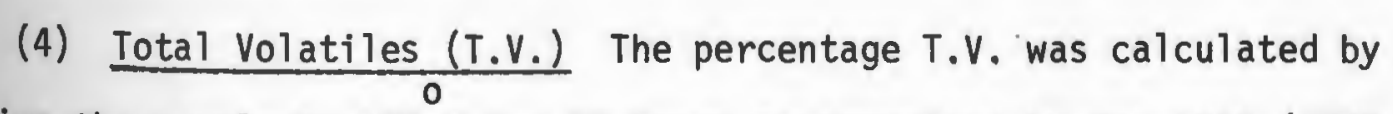
drying the sample at $105 \mathrm{C}$ for 18 hours as described by the AOAC (1970, Section 24.003).

(5) Ash The ash content was estimated by igniting the sample at $525 \mathrm{C}$ to a constant weight as mentioned in the Official Methods of Analys is (AOAC, 1970, Section 18.012). 
(6) Yield The yield of FPC was calculated according to the following formula:

$$
\% \text { yield }=\frac{\text { (wt FPC produced) }(100)}{\text { wt ground fresh frozen raw meat }}
$$

(7) Water Holding Capacity Two gms of FPC was shaken with $25 \mathrm{ml}$ tap water for 2 minutes and centrifuged at $480 \times \mathrm{g}$ for 5 minutes. The supernatant liquid was decanted off. The wet residue was weighed and the percentage of water held was calculated.

(8) 0il Holding Capacity Two gms of FPC was shaken with $25 \mathrm{ml}$ of corn oil for 2 minutes. The mixture was centrifuged at $480 \times \mathrm{g}$ for 5 minutes. The supernatant oil was decanted off, the residue was weighed and the percentage of oil held was calculated. The water and oil holding capacities were studied following Jayatilleke (1971). 


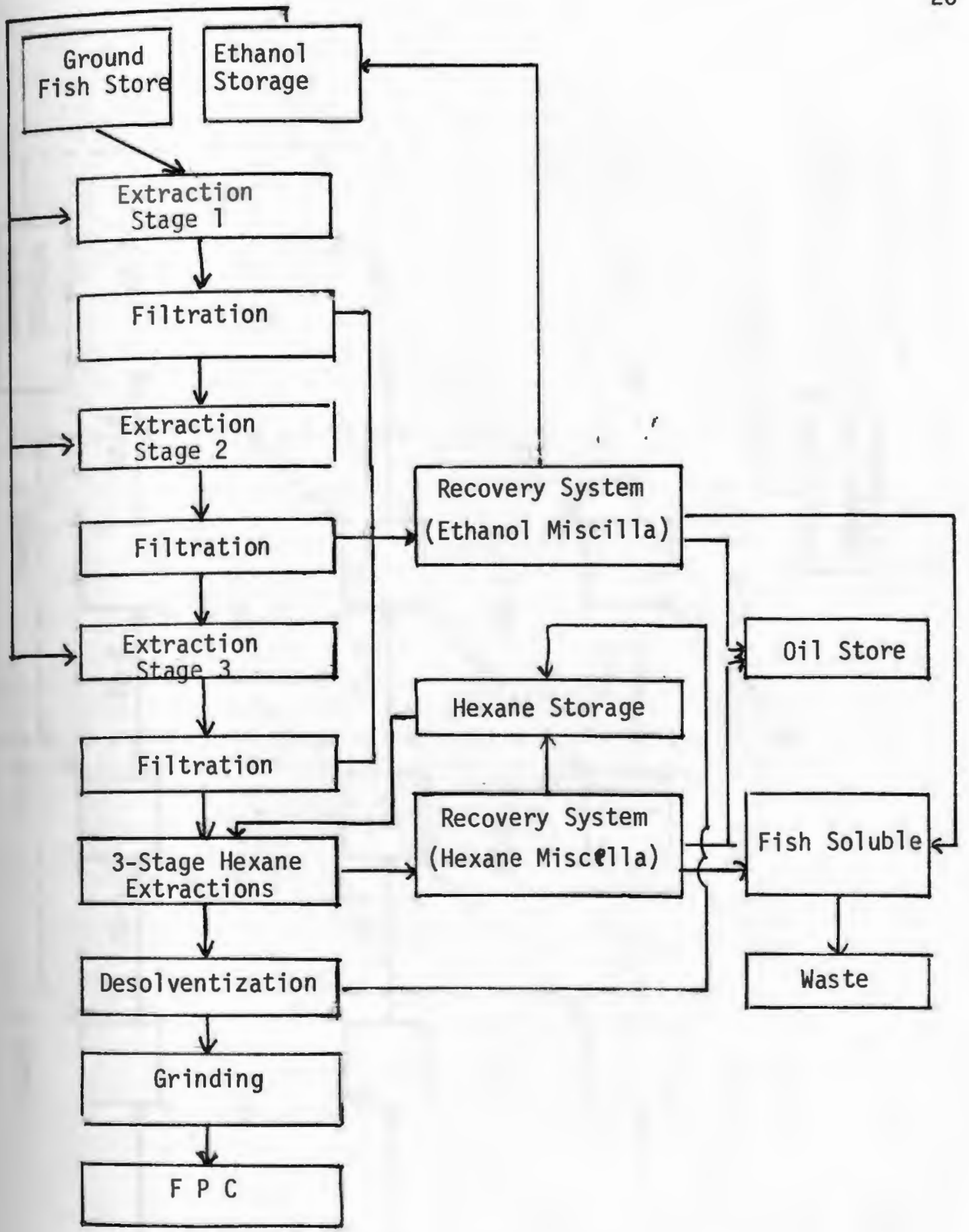

Figure 1. Schematic Diagram of 3-Stage Batch Crosscurrent Solvent Extraction Process 


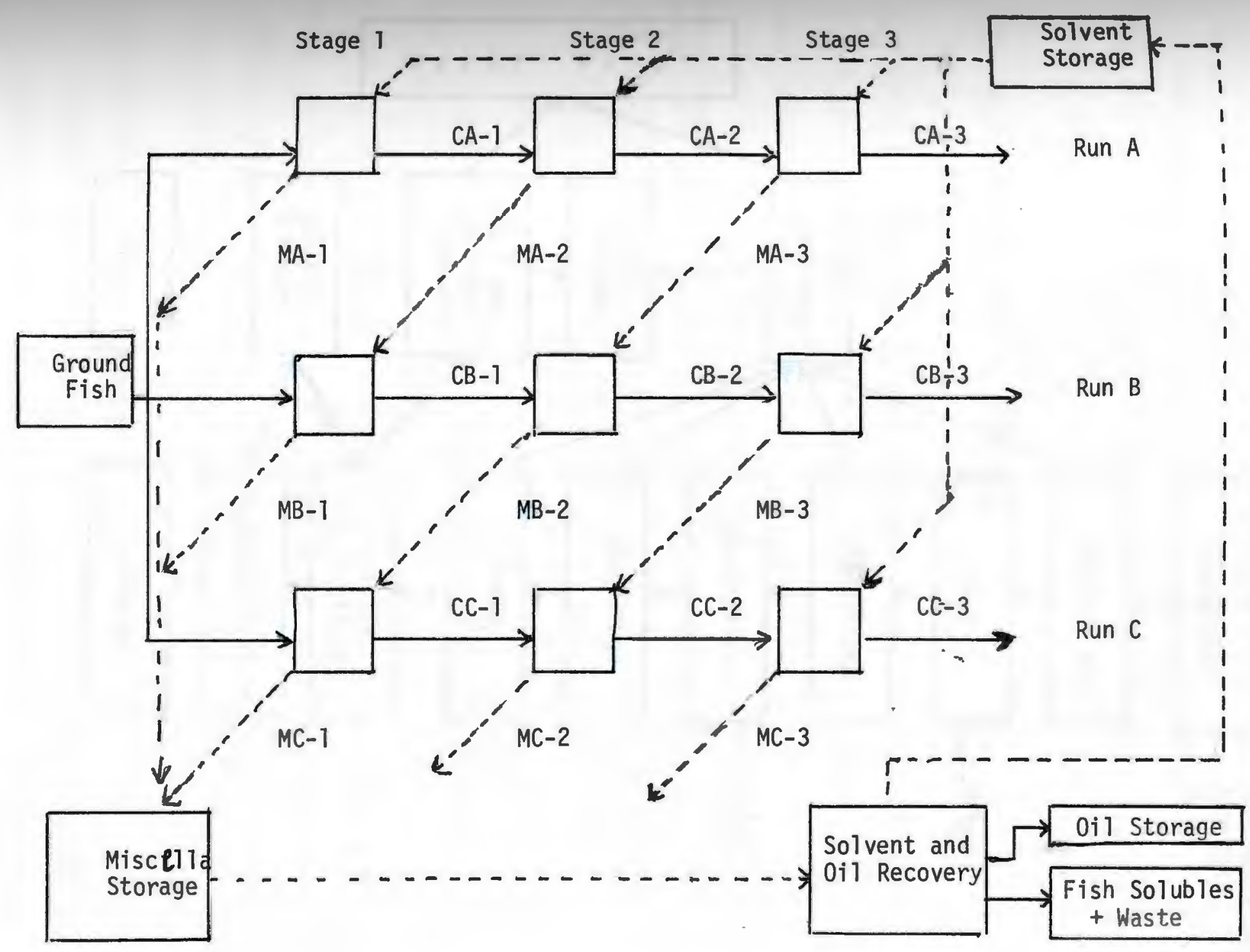

Figure 2. Schematic Diagram of 3-Stage Batch Countercurrent Extraction Process 


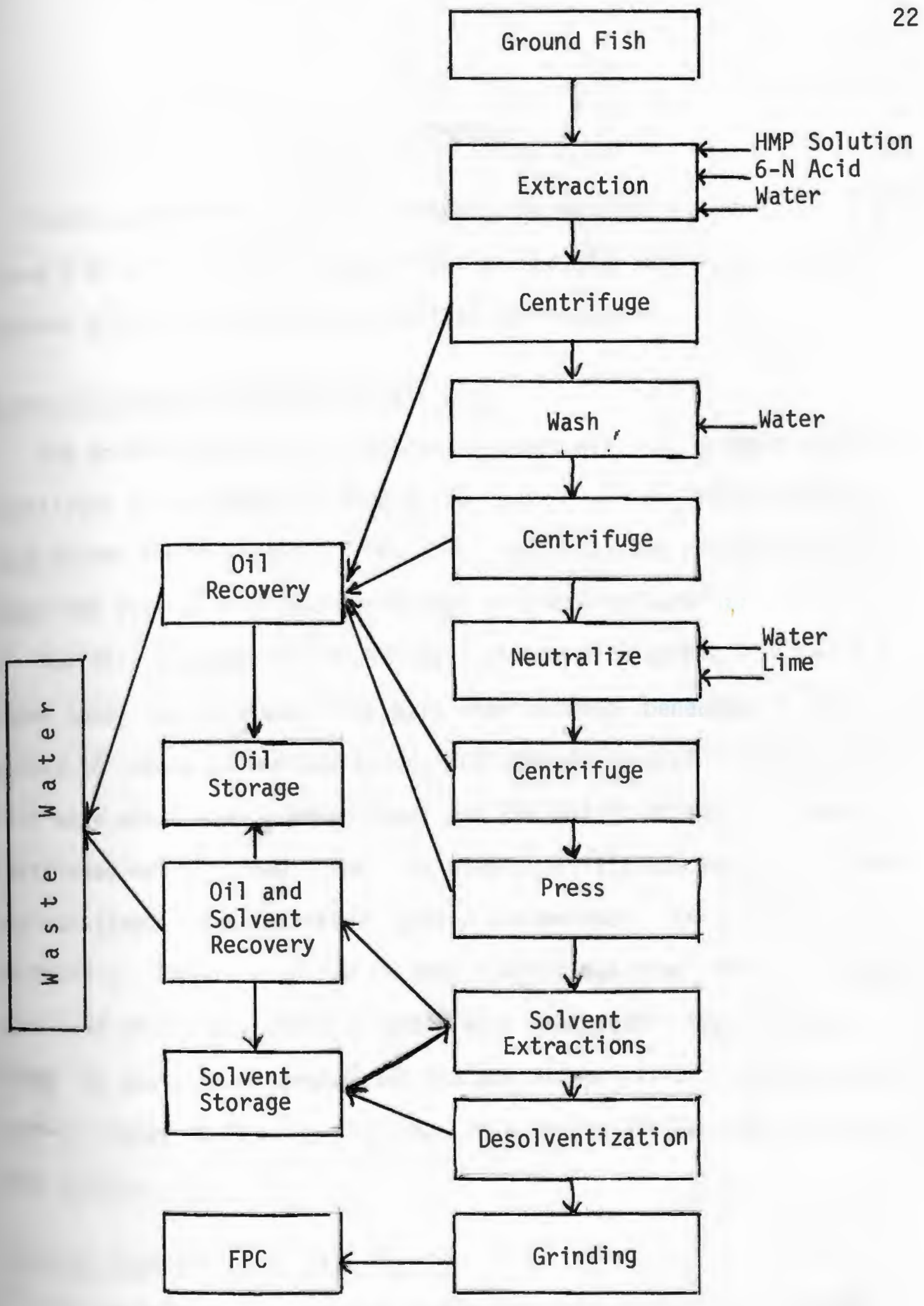

Figure 3. Schematic of Aqueous Phosphate Process 


\section{EXPERIMENTAL}

Unless otherwise specified, extractions were performed at $65^{\circ} \pm 5^{\circ} \mathrm{C}$, using $1 \mathrm{ml}$ of solvent per gram of wet ground fish and stirring for 15 minutes after attaining the extraction temperature.

\section{Stio of Processable Meat to Whole Fish}

The percentage yield of processable meat with and without backbone cartilages in one batch of five spiny dogfish and one batch of four sand sharks was worked out. This also indicated the relationship between the size of fish and percentage of processable meat.

For this purpose, the fishes were washed with water, wiped with a paper towel and weighed. They were then skinned, beheaded, gutted, washed to remove slimes and blood, and allowed to drain. The processed fish were wiped with a paper towel and the weight of each fish with cartilages was recorded. The fish were next filleted and the fillets and cartilages were separated, pooled and weighed. The data are shown in Table 1. While the yield in both species was about $50 \%$, it appears that sand sharks may yield slightly more processable meat than dogfish. It was also observed that the percentage yield of processable meat is higher in the bigger fishes than in the smaller fish of the same species.

\section{Ycal Composition of Fish Muscle}

The percentage composition of two consignments of spiny dogfish and one consignment of sand shark in respect to urea, total volatiles, pro- 
tein, lipids, and ash was determined and recorded in Table 2. The urea contents of two batches of spiny dogfish did not vary significantly but there was considerable difference in their lipid and moisture contents. The sand shark sample contained more protein and urea than the spiny dogfish samples.

Tfect of Temperature on Urea Extraction

The effect of temperature $\left(25^{\circ}, 45^{\circ}\right.$, and $\left.60^{\circ} \mathrm{C}\right)$ on extractability of urea, lipids and moisture has been studied. The experiment was conducted on the crosscurrent principle using 95\% ethanol and commercial hexane as solvents. In one run; extraction with hexane was omitted to compare lipid extraction with the runs in which both solvents were used. The FPC's thus produced were analyzed and the results are presented in Table 3. More urea was extracted with an increase in temperature but there was no difference in lipid extractability in small range of change of temperature $\left(25^{\circ}\right.$ and $\left.45^{\circ} \mathrm{C}\right)$. Considering the above observation, it may be inferred that hexane has a marked capability for extracting lipids, since the product prepared without hexane contained $14.2 \%$ lipid as compared with 1 ess than $1.5 \%$ after one hexane wash.

\section{Sct of Ethanol Concentration on Urea Extraction}

The effect of the concentration of ethanol used in the first stage on urea removal is shown in Table 4. The initial extraction with different ethanol-water ratios was followed by two $95 \%$ ethanol and two hexane stages. Extractions were crosscurrent. The $20 \%$ ethanol treat- 
ment was most efficient in extracting urea $(0.040 \%)$, while the yield of FPC was also lowest, an indication of greater proteolytic enzyme activity than in the $40-95 \%$ ethanol treatments.

ct of $\mathrm{pH}$ on the Processing of Shark Meat by the Aqueous Phosphate exss

In this series of experiments the initial aqueous extractions were conducted at $\mathrm{pH} 5.0,4.5,4.0$, and 3.5 and at temperatures of $25^{\circ}$ and ${ }^{\circ} \mathrm{C}$ to show the combined effect of temperature and $\mathrm{pH}$ on extractability of urea in the presence of $1 \%$ hexametaphosphate (HMP). The filter cakes obtained after one wash of the HMP-precipitate were extracted twice with $95 \%$ ethanol to observe the dehydrating and lipid extracting ability of the ethanol. From the chemical analysis of the products, Table 5, it can be seen that the urea content of each sample was low $(0.060-0.082 \%)$ at 25 and even lower $(0.024-0.035 \%)$ at $45 \mathrm{C}$. The lipid contents were very high, while total volatiles were higher than usual for FPC.

fect of HMP Concentration on Yield of FPC

Ground shark meat was treated wi th $0.5,1.0,2.0$, and $4.0 \%$ of HMP. For the $0.5 \%$ treatment, $1 \mathrm{~g}$ of sodium hexametaphosphate was dissolved in $200 \mathrm{ml}$ water. This solution was added with stirring to $200 \mathrm{~g}$ of fish in a beaker. The mixture was adjusted to $\mathrm{pH} 4.0 \pm 0.1$, heated 0

to $65 \mathrm{C}$ and stirred at that temperature for 15 minutes. The slurry was centrifuged, the supernatant was decanted and $200 \mathrm{ml}$ of water was added to the sediment. After mixing the slurry was centrifuged. The solid residue was pressed to remove more liquid and the press cake 
was extracted twice with $95 \%$ ethanol and twice with hexane, crosscurrently. The products were analyzed and are reported in Table 6 .

It appears that the urea content in the FPC samples was pretty low. The level of total volatiles was still high (11.6-12.7\%). There was not much difference in yield in the samples processed with 1,2 and $4 \%$ HMP, but the yield was slightly lower in the case of the sample treated with $0.5 \%$ HMP. The lipid contents of all the samples of FPC were within the FDA limits.

\section{euntercurrent Solvent Extraction of Ground Meat to Produce FPC}

A comparison of extractability of urea, lipid and moisture by crosscurrent and countercurrent solvent extraction was conducted. Three ethanol and two hexane stages were employed in one set and three ethanol and three hexane stages were used in another set of experiments. The samples of FPC thus produced were analyzed and the results are tabulated in Table 7.

From the analysis of the FPC's it appears that there is no significant difference in yield or residual urea level. Total volatiles were within the acceptable limit. However, the lipid content for FPC produced by the countercurrent process using three ethanol and two hexane extractions was higher than the FDA limit. In other samples it was within the acceptable limit. It is noted that the starting material used for this comparison and in several subsequent experiments contained $13.4 \%$ lipid. 
of Varying the Number of Stages in the Countercurrent Extraction hod

The FPC's produced with several combinations of ethanol and hexane stages in the countercurrent mode were analyzed and the results are tabulated in Table 8. It was observed that three ethanol stages followed by three hexane stages produced the desired result. The urea content could not be lowered below $0.145 \%$ even extracting with a third ethanol stage. The urea content in FPC produced by two stages of ethanol and three stages of hexane was more than double that with three stages of ethanol and two stages of hexane. Lipid and moisture contents were brought down to acceptable values where three stages of extraction with hexane were used. No appreciable difference in yield was observed.

mbination of Aqueous Phosphate Process and Countercurrent Extraction

The analytical results of FPC produced by aqueous phosphate process in combination with various stages of extraction with ethanol (95\%) and hexane are presented in Table 9.

It was observed that extraction of the aqueous phosphate process cake in three ethanol stages followed by three hexane stages produced excellent results. The urea level was brought down to $0.067 \%$ as compared with $1.1 \%$ in raw meat. The moisture and lipid levels were reduced to 8.43 and $0.56 \%$, respectively. The yield was also good.

\section{Ing Quality of Ground Shark Meat in 95\% Ethanol}

The sand shark meat without cartilages was preserved in $95 \%$ ethanol using one $\mathrm{ml}$ ethanol per gram of meat. Samples were stored at room 
temperature $\left(28 \pm 2^{0} \mathrm{C}\right)$ for 24 hours, one week, and 4 weeks. There was also a control sample at zero hour. All were processed by crosscurrent solvent extraction using two additional ethanol and three hexane stages. The composition of the samples of FPC were determined and are presented in Table 10.

The yield was very close in each of the four samples. There were no observable differences in odor, color, texture, or taste of the samples (Table 12).

Wnsory and Functional Properties of FPC

The water and oil holding capacities of FPC samples prepared by crosscurrent, countercurrent, and aqueous phosphate process, and the samples on which keeping quality in ethanol was studied were determined. Corn oil was used in studying the oil holding capacity. The results are placed in Table 12. Observations of color, odor, texture, and taste are also presented in Table 12.

\section{length of Extraction Period}

Ground dogfish meat was extracted for 15, 30 or 60 minutes per stage in the crosscurrent fashion with various combinations of ethanol and hexane stages. In all cases the first extraction was made with $47.5 \%$ ethanol to minimize the urea content of the product. The results are presented in Table 11. It was observed that the FPC produced with six ( 3 ethanol and 3 hexane) 15 minute extractions was comparable in lipid content $(0.74 \%)$ with FPC produced with five ( 3 ethanol plus 2 hexane or 2 ethanol plus 3 hexane) 30 minute ex- 
tractions or five 60 minute extractions with ethanol alone. The best result on lipid removal was obtained when the fish was processed with two ethanol followed by three hexane stages, extracting for 60 minutes in each stage. The lipid content of the FPC was $0.25 \%$, but the urea content was $0.40 \%$. The fish processed by three ethanol followed by two hexane stages for 60 minutes per stage yielded FPC with $0.45 \%$ lipid and $0.128 \%$ urea, while FPC prepared with six 60 minute ethanol extractions had only $0.41 \%$ lipid and no detectable urea. 
Table 1

Estimation of Processable Meat from Whole Fish

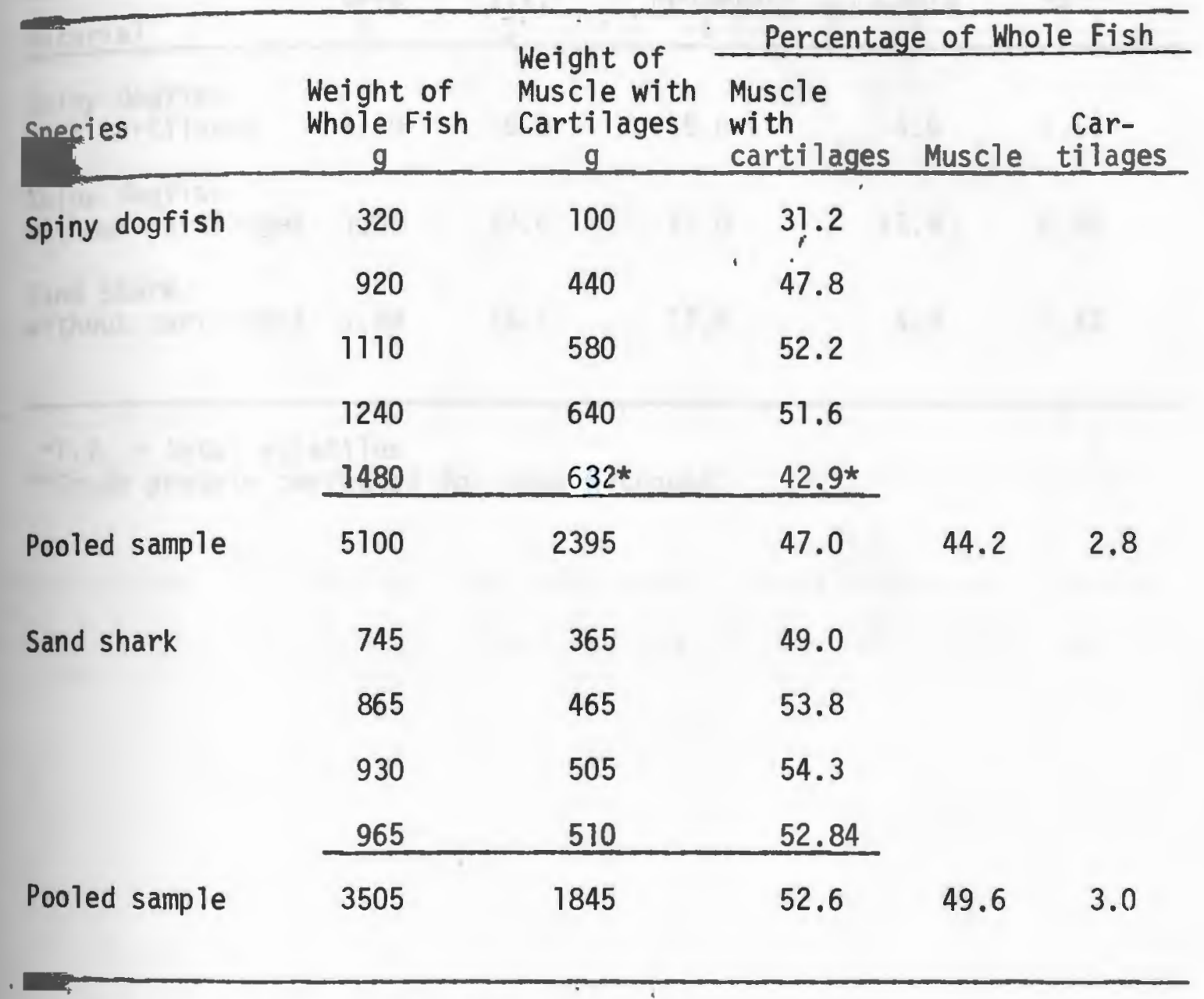

*Some loss was incurred during processing. 
Table 2

Chemical Composition of Ground Shark Meat

\begin{tabular}{|c|c|c|c|c|c|}
\hline Erial & $\begin{array}{l}\text { Urea } \\
\% \\
\end{array}$ & $\begin{array}{l}\text { T.V.* } \\
\%\end{array}$ & $\begin{array}{c}\text { Prote1 } \\
\% \\
\end{array}$ & $\begin{array}{c}\text { Lipid } \\
\% \\
\end{array}$ & $\begin{array}{c}\text { Ash } \\
\% \\
\end{array}$ \\
\hline $\begin{array}{l}\text { Spiny dogfish } \\
\text { with cartilages }\end{array}$ & 1.10 & 75.0 & 15.6 & 4.9 & 1.61 \\
\hline $\begin{array}{l}\text { Spiny dogfish } \\
\text { without cartilages }\end{array}$ & 1.08 & 70.6 & 16.0 & 13.4 & 0.92 \\
\hline $\begin{array}{l}\text { Sand shark } \\
\text { without cartilages }\end{array}$ & 1.44 & 74.5 & 17.4 & 4.0 & 1.12 \\
\hline
\end{tabular}

*T.V. = total volatiles

**Crude protein corrected for urea nitrogen 


\section{Table 3}

Effect of Temperature on the Crosscurrent Solvent Extraction of Urea from Shark Meat

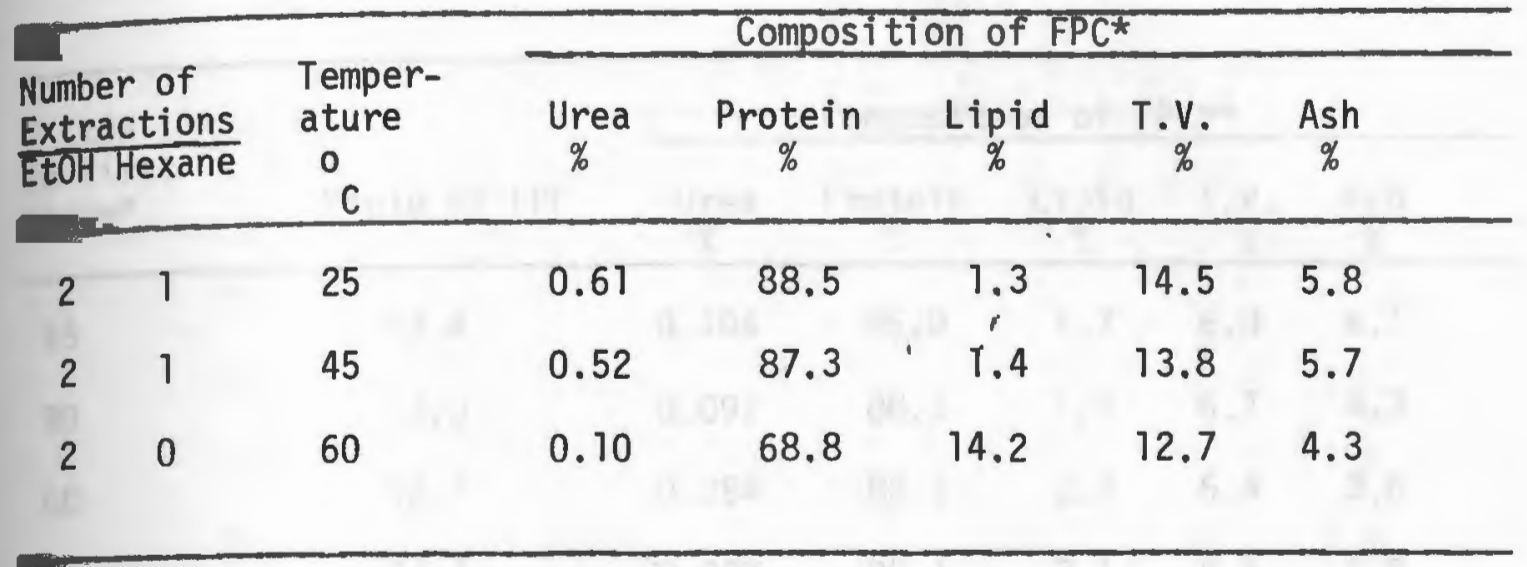

*Raw material, dogfish, with cartilages, contained $1.10 \%$ urea and $4.9 \%$ lipid. 
Table 4

Crosscurrent Solvent Extraction of Shark Meat at $65 \mathrm{C}$ Using Ethanol in Diminishing Order of Concentration for First Stage

\begin{tabular}{llllllll} 
\% EtOH & \multicolumn{5}{c}{ Composition of FPC** } \\
\cline { 3 - 7 } & Yield of FPC & $\begin{array}{c}\text { Urea } \\
\%\end{array}$ & $\begin{array}{c}\text { Protein } \\
\%\end{array}$ & $\begin{array}{c}\text { Lipid } \\
\%\end{array}$ & $\begin{array}{c}\text { T.V. } \\
\%\end{array}$ & $\begin{array}{c}\text { Ash } \\
\%\end{array}$ \\
\hline 50 & 12.4 & 0.104 & 86.0 & 1.7 & 6.8 & 4.1 \\
60 & 13.0 & 0.092 & 88.3 & 1.9 & 6.7 & 4.3 \\
40 & 12.7 & 0.084 & 88.3 & 2.4 & 6.4 & 3.6 \\
20 & 13.1 & 0.088 & 90.1 & 2.1 & 6.6 & 5.9 \\
\hline
\end{tabular}

* Filter cake extracted with 2 additional ethanol and 2 hexane stages. **Raw material was dogfish containing $1.1 \%$ urea and $4.9 \%$ lipid. 
Table 5

Effect of $\mathrm{pH}$ and Temperature in Aqueous Phosphate Process

in Combination with Two-Stage Crosscurrent

Ethanol Extraction

\begin{tabular}{|c|c|c|c|c|c|c|}
\hline \multirow{2}{*}{\multicolumn{2}{|c|}{ Temperature }} & \multicolumn{5}{|c|}{ Composition of FPC* } \\
\hline & & $\begin{array}{c}\text { Urea } \\
\%\end{array}$ & $\begin{array}{c}\text { Protein } \\
\%\end{array}$ & $\underset{\%}{\text { Lipid }}$ & $\begin{array}{l}\text { T.V. } \\
\%\end{array}$ & $\underset{\%}{\text { Ash }}$ \\
\hline \multirow[t]{2}{*}{5.0} & 25 & 0.060 & 68.0 & 12.6 & 14.8 & 4.6 \\
\hline & 45 & 0.033 & 70.5 & 11.0 & 13.8 & 4.7 \\
\hline \multirow[t]{2}{*}{4.5} & 25 & 0.078 & 58.9 & 20.7 & 14.9 & 5.5 \\
\hline & 45 & 0.024 & 64.6 & 15.5 & 14.5 & 5.2 \\
\hline \multirow[t]{2}{*}{4.0} & 25 & 0.082 & 69.6 & 12.5 & 13.9 & 5,0 \\
\hline & 45 & 0.034 & 63.1 & 18.1 & 12.7 & 6.1 \\
\hline \multirow[t]{2}{*}{3.5} & 25 & 0.072 & 72.0 & 10.6 & 12.0 & 5.4 \\
\hline & 45 & 0.035 & 66.3 & 17.2 & 11.0 & 5.5 \\
\hline
\end{tabular}

*Raw material was dogfish with cartilages, $1.1 \%$ urea, $4.9 \%$ lipid. 
Table 6

Treatment wi th Various Concentrations of Sodium Hexametaphosphate (HMP) at $\mathrm{pH} 4.0$ by

Aqueous Phosphate Process* in

Production of FPC

\begin{tabular}{ccccccc} 
HMP & \multicolumn{6}{c}{ Composition of FPC** } \\
\cline { 5 - 8 } $\begin{array}{c}\text { Concentration } \\
\text { a/100 g of }\end{array}$ & $\begin{array}{c}\text { Yield } \\
\text { of FPC }\end{array}$ & $\begin{array}{c}\text { Urea } \\
\text { fish }\end{array}$ & $\begin{array}{c}\text { Protein } \\
\%\end{array}$ & $\begin{array}{c}\text { Lipid } \\
\%\end{array}$ & $\begin{array}{c}\text { T.V. } \\
\%\end{array}$ & $\begin{array}{c}\text { Ash } \\
\%\end{array}$ \\
\hline 0.5 & 16.4 & 0.049 & 85.0 & 0.42 & 12.3 & 1.8 \\
1.0 & 16.9 & 0.049 & 85.2 & 0.28 & 12.3 & 2.6 \\
2.0 & 17.2 & 0.053 & 81.5 & 0.17 & 11.6 & 3.4 \\
4.0 & 17.1 & 0.049 & 83.1 & 0.15 & 12.7 & 4.4 \\
\hline
\end{tabular}

*HMP precipitate received one aqueous wash followed by two ethanol and three hexane crosscurrent extractions.

** Raw material was sand shark containing $1.44 \%$ urea and $4.0 \%$ lipid. 
Table 7

Comparison of FPC from Crosscurrent and Countercurrent Solvent

Extraction of Shark*

\begin{tabular}{|c|c|c|c|c|c|c|c|c|}
\hline 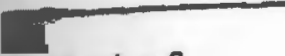 & & & & & osition & $f F C^{\star}$ & & \\
\hline $\begin{array}{c}\text { Method of } \\
\text { etion }\end{array}$ & $\begin{array}{r}\text { Nur } \\
\text { St } \\
\text { EtOH }\end{array}$ & $\begin{array}{l}\text { Der ot } \\
\text { ges } \\
\text { Hexane }\end{array}$ & of FPC & $\begin{array}{c}\text { Urea } \\
\% \\
\end{array}$ & $\begin{array}{c}\text { Protein } \\
\%\end{array}$ & $\underset{\%}{\text { Lipid }}$ & T.V. & $\begin{array}{c}\text { Ash } \\
\%\end{array}$ \\
\hline Crosscurrent & 3 & 2 & 13.4 & 0.162 & 87.7 & 0.53 & 8.59 & 2.32 \\
\hline countercurrent & 3 & 2 & 13.1 & 0.160 & 88.4 & 0.90 & 9.68 & 2.29 \\
\hline Crosscurrent & 3 & 3 & 14.0 & 0.140 & 92.5 & 0.47 & 4.90 & 2.20 \\
\hline Countercurrent & 3 & 3 & 12.5 & 0.145 & 89.6 & 0.61 & 9.40 & 1.96 \\
\hline
\end{tabular}

*Raw material was dogfish containing $1.08 \%$ urea and $13.4 \%$ lipid. 


\section{Table 8}

Effect of Variation in Number of Stages in Countercurrent Extraction of

Shark Meat for Production of FPC

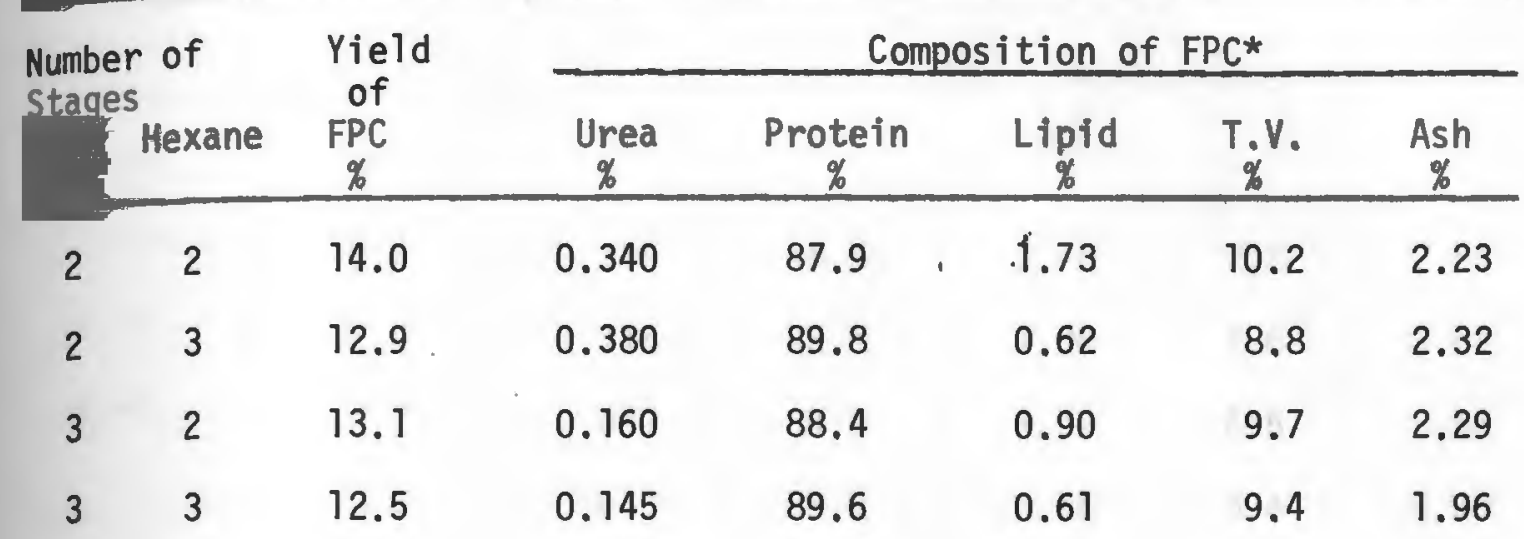

* Raw material was dogfish containing $1.08 \%$ urea and $13.4 \%$ lipid. 


\section{Table 9}

FPC Produced by Aqueous Phosphate Process with Variation in Number of Stages of

Countercurrent Solvent Extraction

\begin{tabular}{|c|c|c|c|c|c|c|c|}
\hline \multirow{2}{*}{$\begin{array}{l}\text { Number } \\
\text { Stages } \\
\text { EtOH }\end{array}$} & \multirow{2}{*}{$\begin{array}{l}\text { of } \\
\text { Hexane }\end{array}$} & \multirow{2}{*}{$\begin{array}{l}\text { Yield } \\
\text { of } \\
\text { FPC } \\
\%\end{array}$} & \multicolumn{5}{|c|}{ Composition of FPC* } \\
\hline & & & $\begin{array}{c}\text { Urea } \\
\%\end{array}$ & $\begin{array}{c}\text { Protein } \\
\%\end{array}$ & $\underset{\%}{\operatorname{Lipid}}$ & $\begin{array}{c}\text { T.V. } \\
\%\end{array}$ & $\begin{array}{c}\text { Ash } \\
\%\end{array}$ \\
\hline 2 & 2 & 12.4 & 0.115 & 86.5 & 2.10 & 7.2 & 2.87 \\
\hline 2 & 3 & 12.4 & 0.116 & 86.6 & 1.06 & 7.6 & 2.82 \\
\hline 3 & 2 & 12.7 & 0.067 & 84.2 & 1.52 & 8.5 & 3.55 \\
\hline 3 & 3 & 12.7 & 0.067 & 88.2 & 0.56 & 8.4 & 3.83 \\
\hline
\end{tabular}

*Raw material was dogfish containing $1.08 \%$ urea and $13.4 \%$ lipid. 
Table 10

Keeping Quality of Ground Shark Meat in $95 \%$ Ethanol at $28 \pm 2^{\circ} \mathrm{C}$

\begin{tabular}{lcccccc}
\hline $\begin{array}{l}\text { Doriod of } \\
\text { Erva- }\end{array}$ & $\begin{array}{c}\text { Yield } \\
\text { of FPC }\end{array}$ & $\begin{array}{c}\text { Urea } \\
\%\end{array}$ & $\begin{array}{c}\text { Protein } \\
\%\end{array}$ & $\begin{array}{l}\text { Lipid } \\
\%\end{array}$ & $\begin{array}{c}\text { T.V. } \\
\%\end{array}$ & $\begin{array}{c}\text { Ash } \\
\%\end{array}$ \\
\hline Thours & 16.6 & 0.131 & 87.3 & 0.15 & 12.7 & 1.98 \\
24 hours & 17.4 & 0.162 & 87.6 & .0 .08 & 14.0 & 1.88 \\
1 week & 16.8 & 0.181 & 84.9 & 0.13 & 11.1 & 1.98 \\
4 weeks & 16.0 & 0.162 & 90.4 & 0.20 & 8.1 & 1.98
\end{tabular}

* Raw material was sand shark containing $1.44 \%$ urea and $4.0 \%$ lipid. crosscurrent extractions with 2 additional ethanol and 3 hexane stages. 
Table 11

Effect of Varying Length of Extraction Period in

Production of FPC from Shark Meat

by Crosscurrent Solvent Extraction

\begin{tabular}{|c|c|c|c|c|c|c|c|c|}
\hline \multirow{2}{*}{$\begin{array}{l}\text { Sam- } \\
\text { ole }\end{array}$} & \multirow{2}{*}{$\begin{array}{l}\text { Period } \\
\text { of ex- } \\
\text { traction } \\
\text { Minutes }\end{array}$} & \multirow{2}{*}{$\begin{array}{l}\text { Number } \\
\text { of } \\
\text { Stages } \\
\text { EtOH }\end{array}$} & \multirow{2}{*}{ Hexane } & \multirow{2}{*}{$\begin{array}{c}\text { Yield } \\
\text { of } \\
\text { FPC } \\
\% \\
\end{array}$} & \multicolumn{4}{|c|}{ Composition of FPC* } \\
\hline & & & & & $\begin{array}{c}\text { Urea } \\
\% \\
\end{array}$ & $\begin{array}{c}\text { Protein } \\
\% \\
\end{array}$ & Lipid & $T_{\dot{\%}} . V$, \\
\hline 1 & 15 & 3 & 3 & 13.7 & 0.124 & 9.3 .1 & 0.74 & 5.06 \\
\hline 2 & 15 & 5 & 0 & 13.2 & 0.025 & 89.3 & 4.04 & 5.85 \\
\hline 3 & 15 & 6 & 0 & 13.2 & 0.017 & 92.9 & 3.20 & 6.02 \\
\hline 4 & 30 & 2 & 2 & 14.8 & 0.504 & 94.6 & 1.65 & 4.65 \\
\hline 5 & 30 & 2 & 3 & 15.2 & 0.400 & 92.9 & 0.78 & 5.02 \\
\hline 6 & 30 & 3 & 2 & 16.2 & 0.156 & 95.2 & 0.87 & 4.72 \\
\hline 7 & 30 & 3 & 3 & 15.1 & 0.184 & 93.4 & 0.57 & 4.82 \\
\hline 8 & 30 & 5 & 0 & 14.7 & 0.033 & 88.1 & 3.19 & 6.35 \\
\hline 9 & 30 & 6 & 0 & 14.7 & 0.017 & 90.8 & 1.50 & 6.49 \\
\hline 10 & 60 & 2 & 2 & 13.8 & 0.396 & 95.1 & 1.21 & 4.66 \\
\hline 11 & 60 & 2 & 3 & 13.6 & 0.400 & 92.4 & 0.25 & 4.93 \\
\hline 12 & 60 & 3 & 2 & 14.0 & 0.128 & 93.8 & 0.45 & 4.64 \\
\hline 13 & 60 & 5 & 0 & 12.0 & 0 & 93.8 & 0.67 & 6.08 \\
\hline 14 & 60 & 6 & 0 & 12.7 & 0 & 93.8 & 0.41 & 6.10 \\
\hline
\end{tabular}

*Raw material was dogfish containing $1.08 \%$ urea and $13.4 \%$ lipid. 
Table 12

The Sensory Evaluation and Functional Properties of FPC from Shark

\begin{tabular}{|c|c|c|c|c|c|c|c|c|c|c|c|}
\hline $\begin{array}{c}\text { Sample } \\
\text { no. }\end{array}$ & $\begin{array}{l}\text { Method of } \\
\text { tion with } \\
\text { Method }\end{array}$ & $\begin{array}{l}\text { Extra } \\
\text { Stage } \\
\text { EtoH }\end{array}$ & $\begin{array}{l}- \\
\text { Hexane }\end{array}$ & Color & Odor & Tas te & Texture & $\begin{array}{c}\text { \%HO } \\
2 \\
\text { Held }\end{array}$ & $\begin{array}{l}\% \text { oil } \\
\text { Held }\end{array}$ & $\begin{array}{l}\text { Rèmarks } \\
011 \\
\%\end{array}$ & $\underset{\%}{\text { Urea }}$ \\
\hline 1 & $\begin{array}{l}\text { Cross- } \\
\text { current }\end{array}$ & 3 & 2 & $\begin{array}{l}\text { Light } \\
\text { cream }\end{array}$ & $\begin{array}{l}\text { Faintly } \\
\text { amine }\end{array}$ & $\begin{array}{l}\text { Slightly } \\
\text { fishy }\end{array}$ & good & 340.00 & 248.00 & 0.53 & 0.162 \\
\hline 2 & $\begin{array}{l}\text { Counter- } \\
\text { current }\end{array}$ & 3 & 2 & $\begin{array}{l}\text { Yellow- } \\
\text { ish cream }\end{array}$ & $\begin{array}{l}\text { Odor- } \\
\text { less }\end{array}$ & $\begin{array}{l}\text { STight7y } \\
\text { fishy }\end{array}$ & good & 340.00 & 250.00 & 0.90 & 0.160 \\
\hline$\overline{3}$ & $\begin{array}{l}\text { Counter- } \\
\text { current }\end{array}$ & $\overline{3}$ & 3 & $\begin{array}{l}\text { Whitish } \\
\text { cream }\end{array}$ & $\begin{array}{l}\text { Odor- } \\
\text { less }\end{array}$ & Tasteless & good & 340.00 & 298.00 & 0.61 & 0.745 \\
\hline 4 & $\begin{array}{l}\text { Counter- } \\
\text { current }\end{array}$ & 2 & 2 & Yellow & $\begin{array}{l}\text { Rancid, } \\
\text { amine }\end{array}$ & $\begin{array}{l}\text { Rancid } \\
\text { fishy }\end{array}$ & good & 274.00 & 222.00 & 1.73 & 0.340 \\
\hline 5 & $\begin{array}{l}\text { Counter- } \\
\text { current }\end{array}$ & 2 & 3 & $\begin{array}{l}\text { Light } \\
\text { cream }\end{array}$ & $\begin{array}{l}\text { Faintly } \\
\text { amine }\end{array}$ & Fishy & good & 358.00 & 233.00 & 0.62 & 0.380 \\
\hline 6 & $\begin{array}{l}\text { A p with } \\
\text { counter- } \\
\text { current }\end{array}$ & 2 & 2 & $\begin{array}{l}\text { Almost } \\
\text { white }\end{array}$ & $\begin{array}{l}\text { Very } \\
\text { faintly } \\
\text { amine }\end{array}$ & $\begin{array}{l}\text { Acidic } \\
\text { slightly } \\
\text { fishy }\end{array}$ & good & 288.00 & 250.00 & 2.70 & 0.115 \\
\hline 7 & $\begin{array}{l}\text { Apwith } \\
\text { counter- } \\
\text { cument }\end{array}$ & 2 & 3 & $\begin{array}{l}\text { Almost } \\
\text { white }\end{array}$ & $\begin{array}{l}\text { Very } \\
\text { faintly } \\
\text { antine }\end{array}$ & $\begin{array}{l}\text { Acidic } \\
\text { slightly } \\
\text { fishy }\end{array}$ & good & 287.00 & 270.00 & 1.06 & 0.115 \\
\hline 8 & $\begin{array}{l}\text { APwith } \\
\text { counter- } \\
\text { current }\end{array}$ & 3 & 2 & $\begin{array}{l}\text { Almost } \\
\text { white }\end{array}$ & $\begin{array}{l}\text { Odor- } \\
\text { less }\end{array}$ & $\begin{array}{l}\text { Acidre } \\
\text { slight ly } \\
\text { fishy }\end{array}$ & good & 253.00 & 299.00 & 1.52 & 0.067 \\
\hline 9 & $\begin{array}{l}\text { AP with } \\
\text { counter- } \\
\text { current }\end{array}$ & 3 & 3 & $\begin{array}{l}\text { Almost } \\
\text { white }\end{array}$ & $\begin{array}{l}\text { Odor- } \\
\text { less } \\
\end{array}$ & $\begin{array}{l}\text { Acidic } \\
\text { slightly } \\
\text { fishy }\end{array}$ & good. & 287.00 & 305.00 & 0.56 & 0.067 \\
\hline
\end{tabular}


Table 12 (continued)

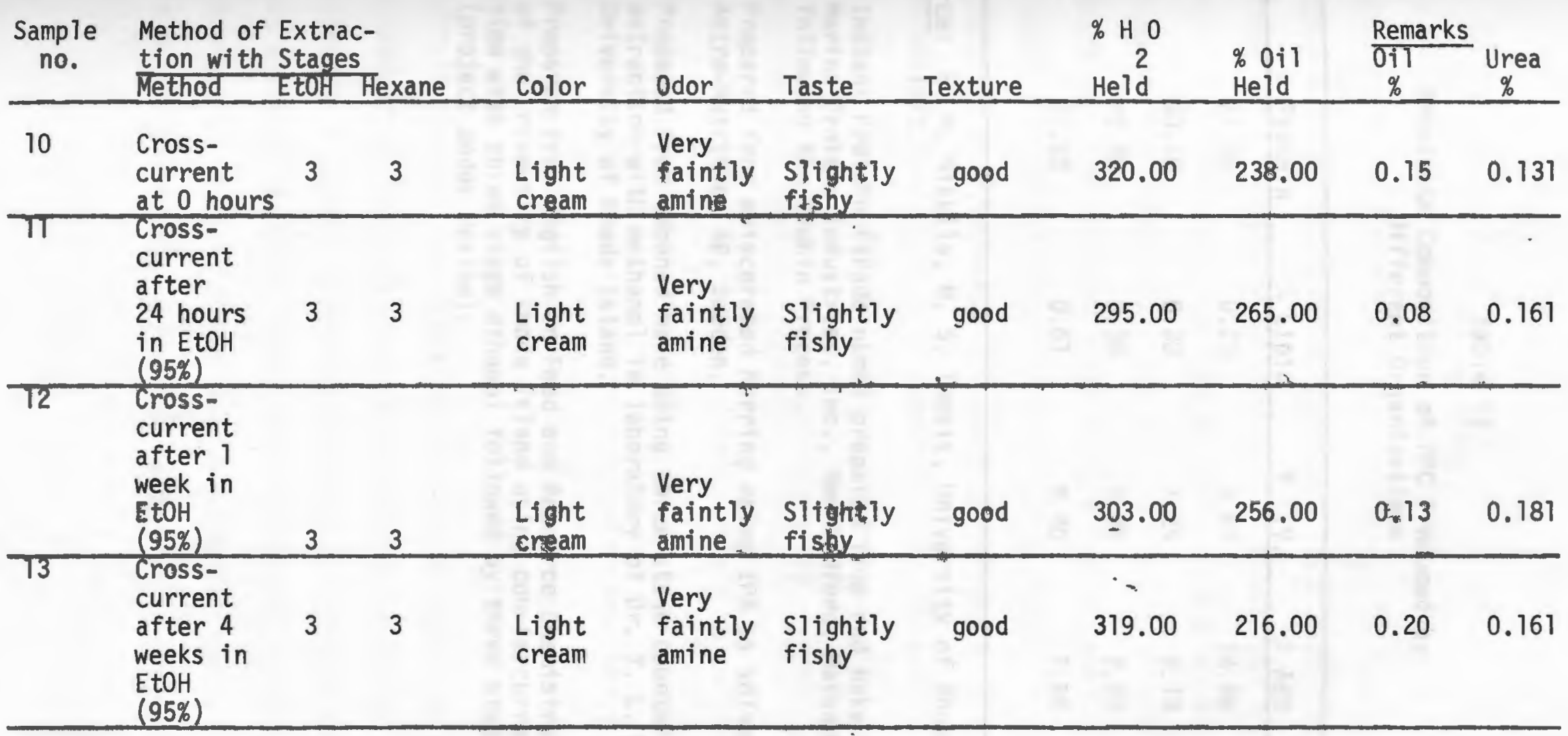


Table 13

Proximate Composition of FPC Produced by Different Organizations

\begin{tabular}{lcccc}
\hline ** & \% Protein & \% Lipid & $\%$ T.V. & $\%$ Ash \\
\hline I & 81.05 & 0.24 & 3.60 & 14.98 \\
II & 90.70 & 0.30 & 3.25 & 8.13 \\
III & 90.80 & 0.39 & 9.95 & 2.09 \\
IV & 89.60 & 0.61 & 9.40 & 1.96 \\
\hline
\end{tabular}

*Source: E. M. Nikkila, M. S. Thesis, University of Rhode Island, 1972.

**I. Instant Protein (trade name) prepared from red hake by Alpine Marine Protein Industries, Inc., New Bedford, Massachusetts, following the Viobin Process.

II. Prepared from eviscerated herring using IPA as solvent by Astra-Nutrition AB, Sweden.

III. Prepared from deboned hake using three stage counter-current extraction with methanol in laboratory of Dr. T. L. Meade, University of Rhode Is land.

IV. Prepared from dogfish in Food and Resource Chemistry Laboratory of the University of Rhode Is land using countercurrent extraction with three stage ethanol followed by three stage hexane (project under review). 


\section{DISCUSSION}

Dr. Samuel Johnson defined fish (Pariser, 1971) as any animal that inhabits the water, but strictly speaking, fish is the term given only to a large class of vertebrates including the bony and cartilagenous fishes. The Elasmobranchii belong to the latter group and sharks belong to the Elasmobranchii. So, the protein concentrate prepared from shark meat can be named "Fish Protein Concentrate". Skates and rays, which also contain urea (Simidu, 1961), and would require identical processing would be excluded by the term "Shark Protein Concentrate". Therefore, it is suggested that the product described in this thesis be named "Fish Protein Concentrate".

\section{Solvents-General Considerations}

The selection of solvents is greatly dependent on their ability to extract urea, moisture and lipid. Urea is highly soluble in water, soluble in alcohols, but insoluble in hydrocarbons (Weast, 1969). Water is the most suitable solvent to extract urea, but it also dissolves and removes some protein, leading to a loss of nutrients and reduction in yield, which increases the cost of production and price of the product and decreases the profit margin. Water does not extract lipids. Alcohols extract water from biological tissue. The solvents which are to be selected for FPC production must be available in abundance, or at least there must be potential sources of the materials from which they can be manufactured. In Western countries, 
isopropyl alcohol (IPA) has found its way into the FPC industries, isobutanol has been suggested as a solvent in Chile (Hevia, 1971) and ethanol has been proposed for the producing of FPC in India (Moorjani and Lahiry, 1970). There is a distillery in the Peoples' Republic of Bangladesh (generally known as Bangladesh) where ethanol is manufactured. This industry could be expanded to fulfill the solvent requirements of an FPC industry in Bangladesh.,

Alcohols are not as efficient as the low boiling hydrocarbons for extracting triglycerides. Among the hydrocarbons hexane is relatively cheap and readily available. There is also a mineral oil refinery based on imported crude oil in Bangladesh. So hexane might be available in our country. Hexane may be removed easily during desolventization under reduced pressure and temperature without causing any appreciable damage to the nutritive value of.FPC. It is used in Peru for the production of FPC from fish meal. Neither it nor ethanol is toxic when ingested in very small doses as might be retained as residual solvent in FPC. Hence, ethanol and hexane have been selected for the production of FPC from sharks.

\section{Prea-Source, Effect and Fate}

The urea content of one batch of spiny dogfish was $1.10 \%$ and the second batch contained $1.08 \%$, whereas the urea content of sand shark was $1.44 \%$. These results agreed with the findings of previous workers. Simidu (1961) reported that sharks caught in the Japan sea contain 1-2.3\% urea in their muscle. Alverson and Stansby (1963) reported that spiny dogfish contains urea in its muscle, but they did 
not mention it quantitatively. Osterhaug (1961) reported that the urea content of dogfish may exceed $2.5 \%$. All of them pointed out that urea plays an important role in osmoregulation in Elasmobranchii. West and Todd (1963) pointed out that when certain proteins are dissolved in strong urea solution, their molecular weight becomes less, indicating the rupture of loose linkages (non-peptide) and formation of smaller particles. This finding may be utilized in solving the problem of osmoregulation in Elasmobranchii. The same author also pointed out that urea is the end product in protein metabolism in humans and a typical $68 \mathrm{~kg}$ subject had $5.74 \mathrm{~g}$ of urea nitrogen in his body pool, which represented a urea space of 33.8 liters. In the human, urea usually represents $80-90$ percent of the total urinary nitrogen. So, the small residual urea in FPC will not be a physiological problem to humans or other animals. Neither human nor any other mono-gastric animal can utilize urea nitrogen for the purpose of synthesizing protein as the cattle do (0sterhaug, 1961).

Suyama and Tokuhiro (1954b) reported that decomposition of muscle urea in $\mathrm{C}$. melanopterus began as low as $80 \mathrm{C}$, the amount of urea and the intensity of the biuret reaction decreasing with increasing temperature. Osterhaug (1961) reviewed reports in the Fishing Gazette of 1917, concerning canned shark meat. In the report, it was pointed out that after shark meat had been in the can two or three months, the flesh became soft and flabby and fairly reeked with the pungent oil, making them positively nauseating. She also cited in the Pacific Fisherman of 1917 that progressive detinning of the interior of cans 
by ammonium hydroxide obtained from urea results in the absorption of tin by the fish and renders it unsuitable for food. These findings indicate the unsuitability of Elasmobranchs in the canning industry.

Simidu et al., (1952) measured $\mathrm{NH}_{3}$ production during storage of shark flesh. It occurs in two stages, the first due to urease present in the muscle and the second due to urease produced by putrifying bacteria. The activity of urease preparation extracted at intervals during storage was proportional to the $\mathrm{NH}$ content of the muscle. In the second case the $\mathrm{NH}$ production was proportional to the growth of microorganisms. Both the enzymatic and microbial spoilage of fish of the family Elasmobranchii occurs in raw meat in storage, if the temperature is not low enough to stop enzymatic action.

The above mentioned problems may be overcome by producing FPC. During processing, the enzymatic activity can be destroyed, the growth of microbes can be retarded, and the urease substrate, urea, can be lowered substantially.

Urea Removal

The removal of urea from shark meat was tested with simple solvent extraction and aqueous phosphate methods. The effect of varying temperature, concentration of ethanol in the first stage, and number of stages on extraction of urea from shark meat was studied. The comparison between crosscurrent and countercurrent extraction of shark meat in respect to extractability of urea was performed.

It was observed (Tables 3 and 5) that solubility and removal of urea from shark meat by ethanol and water increased with an increase in temperature. 
The urea contents of FPC samples were $0.61,0.52$ and $0.10 \%$ at 25 , 0 45 and $60 \mathrm{C}$, respectively, after two crosscurrent ethanol extractions of ground dogfish (Table 3 ). At the time of performing this set of experiments a very useful observation was made. It was found that the slurries produced at $45^{\circ}$ and $25^{\circ} \mathrm{C}$ were viscous and it was very difficult to separate miscella from the cake by filtration or pressing. 0 But at $60 \mathrm{C}$, the protein in the slurry was stiffer on account of coagulation of muscle protein and it was easier to separate miscella from cake by either filtration or pressing.

Since Suyama et a1., (1954) noted that urea starts decomposing $80^{\circ} \mathrm{C}$ and muscle protein is denatured at $60^{\circ} \mathrm{C}$, it was decided to at $80 \mathrm{C}$ and muscle protein is denatured at $60 \mathrm{C}$, it was decided to conduct other experiments within the range of $60-70 \mathrm{C}$.

With the aqueous phosphate process plus two crosscurrent ethanol extractions (Table 5), urea residues were reduced to 0.082 and $0.034 \%$ 0 at temperatures of 25 and $45 \mathrm{C}$, respectively.

An experiment was set up to observe the effect of different concentrations of ethanol (20\%, $40 \%, 60 \%, 80 \%$ and $95 \%$ ) on extraction of urea from shark meat for the production of FPC. The results are listed in Table 4. It was observed that $20 \%$ ethanol was most efficient in extracting urea but the FPC production was lower than with other concentrations. There was no marked difference in urea extracting capability between $40-90 \%$ ethanol.

The concentrations of urea in FPC produced by crosscurrent and countercurrent solvent extraction methods were not significantly different. This can be seen in Table 7 . 
The urea concentration in FPC produced from dogfish meat by changing the number of extraction stages is noted in Table 8. It was observed that urea concentration with two ethanol stages plus two or three hexane stages were 0.34 and $0.38 \%$, whereas the values were 0.16 and $0.14 \%$ in FPC prepared with three ethanol stages and two or three hexane stages. When FPC was prepared using five stages of extraction with ethanol there was only a trace of residual urea (Table 11). With six ethanol stages, no urea was detected in the FPC.

In a later experiment at $65^{\circ}$ (Table 9), the aqueous phosphate process in combination with three countercurrent ethanol followed by three countercurrent hexane extractions yielded FPC with $0.067 \%$ urea, lower than either crosscurrent or countercurrent solvent extraction alone.

Lipids

The Food and Drug Administration (FDA) of the U.S.A. has prescribed the limit of lipid content in FPC at $0.5 \%$. It has been observed that if the lipid content is allowed to exceed that limit, the FPC may get rancid. So lipid causes a problem in FPC.

The lipids in aquatic animals as a whole are characterized by a high degree of unsaturation. In the elasmobranchs, alkozyglyceride and squalene partly or entirely take over the function of triglyceride (Lovern, 1962). 0lcott (1962) pointed out that highly unsaturated lipids of fish are readily susceptible to attack by molecular oxygen. The reaction proceeds by a free radical mechanism and is, therefore, characterized by an induction period followed by an accelerating rate 
of oxygen absorption with concurrent development of peroxides, rancid odor and polymerized products. The rate of initiation of free radical reactions is increased by heat, light, irradiation and heavy metals. Free radicals react with oxygen to yield peroxy radicals, which then abstract hydrogen from the substrate yielding hydroperoxides and new free radicals. A single chain is thus continued, but new chains result from the breakdown of hydroperoxides to give new free radicals. Ultimately a plethora of reaction products results. Lea (1962) reports that lipoperoxides, aldehydes, acids, ketohydroxy and epoxy compounds cause off-odors and flavors. These are the autoxidation products from unsaturated fats. Off-odors and flavors make the products unacceptable to the consumers. So the FDA limited the lipid content in FPC as mentioned earlier.

Joslyn (1970) emphasized that the following factors are involved in completeness of extraction of lipids:

1. Nature of the material to be extracted

a. Comparative rates at which the components pass into solution

b. Effect of one component upon the solubility of the other

c. Size of the particles of which the mixture is composed

d. The relative amounts of the more and less soluble compounds

2. Nature of solvent
a. Diffusibility
b. Solvent power 
3. Surface offered to the solvent

4. Rate at which the solvent circulates through the extraction shell

5. Relative amounts of solvent and material to be extracted

He also emphasized that the development of off-flavor has been ascribed to the degradation of lipids either catalyzed by enzymes or initiated by autoxidation.

\section{Lipid in Raw Materials}

Three batches of fish were used as raw material in these experiments. There were two batches of spiny dogfish with lipid contents in the meat of 4.9 and $13.4 \%$ and one batch of sand shark with $4.0 \%$ lipid in meat (Table 2). On a dry basis these amount to $19.6,45.5$ and $15.7 \%$, respectively.

\section{Lipid in FPC}

The lipid content of FPC depended upon the lipid content of the starting material. When the lipid content of the raw fish was $13.4 \%$, the FPC contained $0.54 \%$ lipid, while the lipid content of FPC was below $0.2 \%$ when the lipid in the raw material was $4.0 \%$ (Tables 7 and 10 ).

It appears from Table 7 that the countercurrent extraction was not as efficient in removing lipid as the crosscurrent extraction. Also lipid levels were not lower in FPC produced by the aqueous phosphate process in combination with countercurrent solvent extraction than the FPC produced by countercurrent solvent extraction alone (Tables 8 and 9). 
The extraction of lipid was better with longer periods of extraction. This can be observed from the values of lipid from the samples $1,7,12 ; 2,8,13$ and $3.9,14$ of Table 11. It appears from samples 11 and 12 that the number of stages of extraction can be reduced from six to five in crosscurrent method using combined solvents by increasing the time of extraction to 60 minutes. Lipid was reduced to the acceptable limit by 6 -stage crosscurrent solvent extraction using only ethanol with the extraction period of sixty minutes in each stage. This experiment suggests that a multistage countercurrent extraction using only ethanol as solvent should be conducted.

It appears that hexane has a marked effect on extraction of lipids of shark muscle after dehydrating the meat; the lipid content in FPC was reduced to $1.4 \%$ from $14.2 \%$ with one extraction at $65 \mathrm{C}$ (Table 3 ).

It was observed that the FPC having higher lipid content $(1.73 \%)$ was more yellow in color, more rancid in odor and more fishy rancid in flavor than any of the FPC samples containing less lipid (Table 12). 
Moisture Removal

The U.S. FDA has prescribed that the total moisture content of FPC should be less than $10 \%$. The reason for reducing moisture content to this level is to check microbial growth and minimize the spoilage of FPC by microorganisms. Desrosier (1970) mentioned that molds can grow on food substrates with as little as $12 \%$ moisture, and some are known to grow in foods with less than $5 \%$ moisture. Bacteria and yeasts require higher moisture levels, usually over 30\%. Both Carpenter (1968) and Desrosier (1970) stated that mold can grow on dry foods or other material like cloth, shoes, etc., when exposed to high humidity conditions. The latter also mentioned that enzyme activity is nil at moisture levels below one percent. So the reduction of moisture content is not to stop enzymatic spoilage but to stop or at least minimize microbial spoilage. Desrosier (1970) also pointed out that in case of fish the requirement of space in storage is reduced to about 40-50\% for dry fish. But in case of FPC, the need of space in storage may be cut to about $20-25 \%$ of fresh fish or even less. The bound water content in cod fish tissues is about 9.5\% (Love, 1968). It was shown by Joslyn (1970) that the rate of reduction of moisture content below $10 \%$ level is independent of the rate at which surface moisture is removed.

Moisture can be reduced from ground fish in two ways: (a) by drying and (b) by solvent extraction. Drying may harden the muscle, make it difficult to extract lipid efficiently and promote lipid oxi- 
dation, rendering the product rancid. Also urea may be concentrated and undergo decomposition to ammonia giving the product off-flavor and odor. Urea and phospholipids will not be extracted in case only non-polar solvent is used to take care of the lipids. So a combination of polar and non-polar solvents was selected for this study.

The moisture contents of the raw materials used in making FPC were $70-75 \%$ for dogfish meat and $75 \%$ for sand shark meat. The moisture contents have been described as percent total volatiles (\% T.V.) in our report. Total volatiles include moisture, residual solvents and other compounds which evaporate during drying. The FPC samples were air dried overnight and no solvent odor could be detected. Other volatile compounds in FPC were considered negligible in comparison to water content. Therefore, T.V. is believed to be mostly moisture.

The T.V. content in FPC produced using two ethanol stages was about 12-14\% (Tables 3, 5, 6 and 10), whereas it was 5-9\% in other samples (Tables $4,7,8,9$ and 11). These variations were possibly the the efficiency of squeezing the cakes in different stages. wreover, T.V. contents can be lowered by drying at reduced temperature and pressure. Under these conditions the nutritive value of FPC may not be impaired.

\section{Foxicity of Residual Solvents}

The maximum level of residual solvent allowed by FDA in FPC in case of IPA is $250 \mathrm{ppm}$ and in case of ethylenedichloride, it is $25 \mathrm{ppm}$. Residual solvent in FPC produced using ethanol and hexane or ethanol alone will not be a toxicity problem. Hexane is only fatal if $50 \mathrm{~g}$ 
is ingested at a time (Dreisbach, 1969). The effect of small doses is not known. Ethanol is commonly ingested by many people and any residue in FPC will not be harmful.

\section{Nutritive Value of FPC}

The daily dietary allowances for protein recommended by the Food and Nutrition Board, National Academy of Sciences National Research Council in 1968 for a $70 \mathrm{~kg}$ man (age group.22-.75 years) and pregnant women is $65 \mathrm{~g}$. Nikkila (1972) postulated that incorporation of $5 \%$ FPC in food $(500 \mathrm{~g})$ per day by some Asian and Arab countries would be sufficient to combat malnutrition. For FPC containing $0.2 \%$ urea, $25 \mathrm{~g}$ $(5 \%$ of $500 \mathrm{~g})$ of FPC would contain $50 \mathrm{mg}$ of residual urea. Ingestion of this quantity of urea will not cause any harm to a man since it will be excreted from the system.

The comparative composition of some FPC's is given in Table 13. It appears that the nutrients of FPC prepared from shark are not inferior to any of the other FPC's. Geiger and Borgstrom (1962) cited the work of Ambe and Sohonie in India, who reported that shark and skate proteins in comparison to casein contain more basic amino nitrogen. They also cited the finding of Masheklar and Sohonie in respect to "essential amino acids". The latter workers found that casein was superior to shark and skate protein in threonine and tryptophan while these same fish proteins were superior to casein in arginine, isoleucine and methionine. They concluded that both shark and skate proteins are quite comparable, if not superior, to casein, as far as amino 
acids are concerned and consequently could readily serve as cheap substitutes in correcting the deficiency of a number of essential amino acids, especially when the other dietary proteins are poor in lysine, arginine and cystine. So, there is no question regarding the value of shark protein in curing malnutrition. However, no work has been done in this aspect with the FPC produced from shark meat in this study. There was no significant difference in color of the FPC produced from either dogfish or sand shark by crosscurrent and countercurrent methods, as shown in Table 12. A11 were cream colored except the sample produced by countercurrent process using two ethanol and two hexane extractions, which was yellow, probably due to high oil and urea content. $0 i 1$ can provide aldehyde by undergoing oxidation, or Maillard reaction, to give a yellow-brown color. Most of the FPC samples had either a very faint smell of amine or were odorless. It was very difficult to distinguish the odorless samples from those with a faint amine odor. The amine odor may be due to retention of amine which was present in the meat. The sample produced with two ethanol and two hexane extractions was rancid because of the high lipid content, $1.73 \%$.

Taste of FPC prepared by countercurrent and crosscurrent solvent extraction methods were mostly slightly fishy. This also might be due to amine. The FPC prepared by aqueous process was acidic in taste as the acid was not completely washed out. So it is suggested that the acid should be neutralized. For neutralization of acid, lime may be used. The texture of FPC was not gritty and it has been recorded 
as good in Table 12. Water holding capacity of FPC prepared from dogfish and shark was as good as the FPC prepared by Jaytilleke et al., (1971). The water holding capacity of our FPC was about 250-350\% and their FPC was 333\%. The oil holding capacity of our sample was 200$300 \%$ whereas the 011 holding capacity of their sample was $183 \%$. At the time of conducting these experiments it was observed that both water- and oil-mixed FPC samples were soft and jt should be possible to mix with any flour without any problem.

\section{Prospect of FPC from Sharks}

Market is the mother of industry. And market is established on need. The growing population needs nutritive foods. Therefore, a market is or will be available for good products. Good food products are judged by flavor, color, odor, taste and texture. As regards utilization of shark meat, Alverson and Stansby (1963) stated that the most profitable use for the carcasses would undoubtedly be as food for humans but development of this usage would be difficult. The principal objections to such development are: (1) in most parts of the U.S.A. there is a strong prejudice against eating shark, (2) sharks contain urea which would have to be removed or fixed in tissues by special processing methods before the flesh would be acceptable to most people and before canning could be accomplished, and (3) compared with many other low-priced and underutilized species of fish, the palatibility of dogfish is low. In addition, religious affairs may also be dragged in along with political implications on accept- 
ability of FPC made out of shark meat. This is, of course, a part of prejudice. About $99 \%$ of the urea is removed in preparing FPC. Organoleptically, shark FPC is believed to be equivalent to FPC produced from other species of fish. The only problem then is prejudice. Shark fins are used in preparing delicious soup in Singapore, Hong Kong and some other countries. Shark meat is consumed as fish and chips in Mexico, the United Kingdom and Australja (Borgstrom, 1962). Shark meat is marketed in fresh condition to some extent in Bangladesh and also in Southern California (Ward et al., 1955). Costa Rica produces dried and salted shark meat for its own consumption (Bergstron and Paris, 1965). The people of affluent countries like the U.S.A., France or Germany may not accept it easily but the people of a country like ours should accept the product when it is not harmful to health and rather contains nutrients which they are lacking. Over and again, they have accepted shark liver oil as medicine. Thus, the only factor which will guide its way into the market is the price and a little education.

The prime objective of this project was removal of urea from shark meat in the production of FPC. The production of FPC was given second importance. The efficiency of extraction of urea, lipid and water has been described earlier. In the following section, the advantage of one complete process over the other (crosscurrent solvent extraction, countercurrent solvent extraction or aqueous phosphate process in combination with solvent extraction) will be discussed. 
In a country like Bangladesh, the multistage (five or six stage) countercurrent solvent extraction process using 95\% ethanol with one hour extraction period is preferred, because ethanol is manufactured in that country. Hexane would have to be imported, of course, importing of hexane may not be a problem. The problem is maintenance of two solvent recovery systems, one for ethanol-water containing oils and trimethylamine or its oxide, and a second for hexane-ethanol-water containing oil mainly. Longer extraction periods, continuous agitation and more effective pressing of the slurry may improve the extraction process. It is suggested that more work should be done on these three issues in a pilot plant scale study to find out whether period and stage of extraction can be shortened. Shortening of either the period of extraction or the number of stages or both will minimize the cost of operation. Moreover, if the plant is based on a limited supply of raw material, the process with the long extraction period and fewer number of stages of extraction in the batches may be more suitable. But, if there is sufficient raw material and solvent to run continuously, the six-stage countercurrent ethanol-hexane procedure with fifteenminute extraction periods may be more advantageous. Sti11, it is better to find out whether prolonging the extraction period in a stage or two with continuous stirring arrangement improves the efficiency of extraction of urea and lipid and also improves the quality of FPC.

The azeotropic isopropanol (AIPA) solvent extraction method for production of FPC developed by BCF is claimed to be a three stage operation. But it appears to be a four stage operation consuming about 
four hours in extracting lipid and water (BCF, 1966). Hevia et al., (1971) described a simple process with isobutanol as solvent in a procedure consuming about five and one-half hours for extracting lipid and moisture. They used $3: 1$ solvent-fish ratio by weight in the first extraction mixing at room temperature for 30 minutes followed by reflux for four hours. After filtration the cake was washed three times using a 1:1 ratio of solvent to extracted, fish. The fat content in the final FPC was $0.3 \%$. The desolventization of wet cake, however, was not very efficient, taking about 18 hours at $60-65 \mathrm{C}$ under a reduced pressure of $25 \mathrm{~mm}$ of $\mathrm{Hg}$. The fat content of their raw material was about $10-20 \%$ on a dry basis. It is questionable whether their method will be suitable for raw material such as shark meat which may contain $30-40 \%$ lipids.

In a country like the U.S.A. the aqueous phosphate process in combination with countercurrent ethanol followed by hexane extraction process may be suitable. As suggested by Spinelli et a1. (1971), the raw materials might be processed at sea by the aqueous process and the cake and oil brought back to the shore. The cake would be processed by countercurrent solvent extraction to produce FPC. 0il may be sold before or after refining. If the whole process is conducted on the bank of a small river or a closed water mass, there is chance of water pollution on account of dumping sulfate along with organic material. Organic materials will deplete oxygen from the water mass. The sulfate may be reduced by microorganisms to hydrogen sulfide, making the water mass poisonous to other organisms. 
Utilization of cartilage will increase the yield of FPC without changing the nutritive quality much. It was observed during the grinding of muscle that the cartilage blocked the screen of the grinder. The suitability of the use of cartilage in the production of FPC should be studied. 


\section{CONCLUSIONS AND RECOMMENDATIONS}

\section{Conclusions}

1. Ninety-eight percent of the urea in shark meat could be removed by use of three countercurrent or crosscurrent ethanol extractions. The urea content of the FPC was $0.16 \%$.

2. Using the aqueous phosphate process with three countercurrent ethanol extractions, residual urea in the FPC was $0.067 \%$.

3. With short ( 15 minute) extraction periods, $95 \%$ ethanol alone was not found to be a suitable solvent for extracting lipids of shark. However, with longer (60 minute) extraction periods, the fat content of dogfish muscle could be reduced to the $0.5 \%$ leve 1 prescribed by the FDA.

4. Using 3 ethanol stages followed by 3 hexane stages in the countercurrent mode, the lipid content of shark FPC was close to the FDA limit.

5. A three-stage ethanol extraction at $60-70^{\circ} \mathrm{C}$ for a period of fifteen minutes in each stage reduced the moisture in fish muscle to $10 \%$ or less.

6. The efficiency of squeezing or pressing was found to play an important role in reducing the urea, lipid and moisture contents of the final product. 
0

7. Separation of miscella from solids was much easier at $60 \mathrm{C}$ and above than at lower temperatures.

8. Filtration or pressing was much easier in later stages than in the first stage.

9. Centrifugation was observed to be essential for the aqueous phosphate process.

10. More than one water wash, and perhaps neutralization of free acid with lime may be required in the aqueous phosphate process to eliminate any acid taste.

11. Based on the bench-scale study, two methods of production of FPC from shark are recommended for Bengladesh. These are: (1) A countercurrent solvent extraction using three ethanol stages followed by three hexane stages, extracting for 15 minutes in each stage, or (2) six-stage (multistage) countercurrent 95\% ethanol extraction with the extraction period of one hour in each stage. For the United States of America, the aqueous phosphate process followed by countercurrent three-stage alcohol extraction plus three-stage hexane extraction is recommended because the product was superior in respect to color, odor and texture to the products obtained by solvent extraction methods. 


\section{Recommendations for Future Work}

1. Systems for recovering ethanol and hexane from respective miscellas should be studied.

2. The maximum level of residual urea in FPC at which no detectable off-smell or off-flavor develops during storage should be determined.

3. The maximum acceptable limit of TMAO and TMA in FPC should be determined so that in a reasonable storage time no bad odors and flavors are developed.

4. The PER value of the product should be determined.

5. The amino acid composition of the FPC should be estimated to get a quantitative idea about the essential amino acids. This is a requirement in food formulation.

6. By sensory evaluation tests, the acceptability of food prepared by incorporating FPC from Elasmobranchii meat should be evaluated.

7. The people in developing and underdeveloped countries should be educated by extension work through governmental machinery to accept FPC from Elasmobranchii. 
APPENDIX

Prescribed Conditions of Food and Drug Administration for Use of FPC as a Food Supplement

(Federal Register 121.1202, February 2, 1967, Whole fish protein concentrate)

(1) The additive is derived from wholesome hake and hake like species of fish handled expeditiously and under sanitary conditions.

(2) The additive is used or intended for use only in the household as a protein supplement in food.

(3) The additive is packaged in consumer-sized units not exceeding 1 pound net weight.

(4) The food additive meets the following specifications:

(a) Protein content shall not be less than 75 percent by weight of the final product.

(b) Moisture content shall not exceed 10 percent by weight of the final product.

(c) Fat content shall not exceed 0.5 percent by weight of the final product.

(d) The additive shall contain not in excess of 100 parts per million fluorides.

(e) The additive shall be free of Escherichia Coli and Pathogenic Organisms, including Salmonella, and shall have a total bacterial plate count of not more than 10,000 per gram of FPC. 
(f) The additive shall have no more than a faint characteristic fish odor and taste.

(g) The additive may contain residues of isopropyl alcohol and ethylene dichloride not in excess of 250 parts per million and 5 parts per million, respectively, when used as solvents in the extraction process. 


\section{REFERENCES}

Alverson, D. L. and Stansby, M. E. 1963. The spiny dogfish (Squalus acanthias) in the Northeastern Pacific. Special Scientific Report - Fisheries No. 447, U. S. Fish and Wildlife Service, Washington, D. C.

Ambrose, M. E., Roche, B. J. and Knobl, G. M. 1969. Semimicro method for determining total lipids. J.A.0.A.C. 52:688.

AOAC. 1970. Official Methods of Analysis. Assn. Offic. Anal. Chemists, Washington, D. C.

Bakken, K. 1962. Technological developments in Scandinavia. In Fish in Nutrition, p. 419. E. Heen and M. Kreuzer, eds. Fishing News (Books) Ltd., London.

BCF (Bureau of Commercial Fisheries). 1966. Marine Protein Concentrate. Fishery Leaflet-584, National Marine Fisheries Service, College Park, Md.

Borgstrom, G. 1962. Trends in utilization of fish and shellfish.

In Fish as Food, Vol. II, p. 694. G. Borgstrom, ed. Academic Press, N. Y.

Borgstrom, G. and Paris, D. C. 1965. The regional development of

fisheries and fish processing. In Fish as Food, Vol. III, p. 358 ,

G. Borgstrom, ed. Academic Press, N. Y.

Brown, N. L. and Miller, H., Jr. 1969. Experimental production of

fish protein concentrate (FPC) from Mediterranean sardines. Comm. Fish. Rev. $31(10): 30$. 
Bullis, H. R., Jr. 1957. Exploratory fishing by the Oregon. Comm. Fish. Rev. $17(10): 1$. (Biol. Abst. 31:6969).

Caiozzi, M., Arrieta, L., Vallaroel, L. and Rauch, E. 1968. The fish protein concentrate story: 7. New method of FPC production for food use. Food Tech. 22(6): 100 .

Carpenter, P. L. 1968. Microbiology, pp. 159, 172, 250-251. W. B. Saunders Co., Phil., Pa. Desrosier, N. W. 1970. The Technology of Food Preservation, pp. 125, 146-148. AVI Publ. Co., Westport, Conn. Dreisbach, R. H. 1969. Handbook of Poisoning, p. 152. Lange Medical Publications, Los Altos, Calif.

Dresoti, A. M. 1962. Technological developments in South Africa. In Fish in Nutrition. E. Heen and R. Kreuzer, ed. Fishing News (Books) Ltd., London.

Du Solier MacGregor, L. and Cavazo, S. F. 1969. Preparing Fish Flour for Human Consumption from Shark Meat. Thesis, Instituto Technologico y de Estudios Superiores de Monterey, Mexico. (Comm. Fish. Abst. 23(10):13).

Fougere, H. 1962. Technological developments in Canada. In Fish in Nutrition, p. 413. E. Heen and R. Kreuzer, eds. Fishing News (Books) Ltd., London.

Geiger, E. and Borgstrom, G. 1962. Fish protein - nutritive aspect. In Fish as Food, Vol. II, p. 49. G. Borgstrom, ed. Academic Press, N. Y. 
Groninger, H. S. 1959. Occurrence and Significance of Trimethylamine Oxide in Marine Animals. Special Fisheries Report \#333. U. S. Fish and Wildlife Service, Washington, D. C. Guttmann, A. and Vandenheuvel, F. A. 1957. The Production of Edible Fish Protein (Fish Flour) from Cod and Haddock. Fish. Res. Board Can. Prog. Rep. Atlantic Coast Sta. 67:29.

Hannesson, G. 1962. Technological developments in Iceland. In Fish in Nutrition, p. 416. E. Heen and R. Kreuzer, eds. Fishing News (Books) Ltd., London.

Hevia, P., Acevedo, F. and Kaiser, S. 1971. Isobutanol as solvent for FPC production. J. Food Sc. 36(4):708.

Haq, S. A. and Muhlihassan, S. 1960. Shark meat flour. Pak. J. Sci. Ind. Res. 3:213.

Hussain, M. M. 1967. Marine and esturine fisheries in East Pakistan with particular reference to trawling. In Transaction of FPC Seminar, Dacca, East Pakistan, p. 68. J. W. Parsons, ed. U. S. AID, Dacca, East Pakistan. Jayatilleke, E. M., Chang, C. M. and Livingston, G. E. 1971. Studies on the functionality of FPC made by an aqueous extraction process. Presented at IFT Annual Meeting, New York (May 26). Josiyn, M. A. 1970. Methods in Food Analysis, pp. 141. Academic Press, N. Y.

Kataoka, A. 1958. Results of tuna long line fishing in the Middle Indian Ocean. J. Shimonoseki Coll. Fish. 6(2):248. (Biol. Abst. $32: 11375)$. 
Lawler, F. K. 1970. Pure fish protein. Food Eng. 42 (August):61. Lea, C. H. 1962. Oxidative deterioration of food lipids. In Symposium on Foods: Lipids and Their Oxidation. H. W. Schultz, E. A. Day, and R. 0. Sinnhuber, eds. The AVI Publ. Co., Westport, Conn. Levin, E. 1959. Fish flour and fish meal by azeotropic solvent processing. Food Tech. 13:132.

Linson, E. V. 1966. Edible Marine Protein Concentration. U. S. Appl. 0ct. 10, 1966. (Fish Protein Concentrate - A Compr. Bibl., p. 22. Library of Congress, Washington, D. C. 1970). Love, R. M. 1968. Ice formation in frozen muscle, p. 118. In Low Temperature Biology in Foodstuffs. J. Hawthorn and E. J. Rolfe, eds. Pergamon Press, N. Y. Lovern, J. A. 1962. The lipids of fish and changes occurring in them during processing and storage. In Fish in Nutrition. E. Heen and R. Kreuzer, eds. Fishing News (Books), Ltd., London. Mahdihassan, S. 1962. Salvaged protein for Pakistan. Current Affairs Bul1. $34: 12$.

Moorjani, M. N. and Lahiry, N. H. 1970. The fish protein concentrate story: 9. Efforts in India. Food Tech. 24(1):56. Nikkila, E. M. 1972. M. S. Thesis, University of Rhode Island. 01 cott, H. S. 1962. Marine products. In Symposium on Foods: Lipids and Their Oxidation. H. W. Schuttz, E. A. Day, and R. 0. Sinnhuber, eds. AvI Publ, Co., Westport, Conn.

Onishi, T. and Higashi, H. 1968. Studies on liquified fish protein. III. Odor and peptide composition of liquified fish protein. Bull. Tokai Reg. Fish Res. Lab. 55:225. (Fish Protein Concentration A Compr. Bibl., p. 24. Library of Congress, Washington, D. C., 1970). 
Osterhaug, K. L. 1961. A literature review on possible uses for dogfish. Comm. Fisheries TL-16, National Marine Fisheries Service, Washington, D. C.

Pariser, E. R. 1962. Technological developments in the U.S.A. In Fish in Nutrition, p. 432. E. Heen and R. Kreuzer, eds. Fishing News (Books) Ltd., London.

Pariser, E. R. 1971. The potential, the probilems and the status of using proteins of aquatic origin as human food. Food Tech. 25(1): 88.

Philips, R. H. 1969. Peruvian farm making FPC and using it in other foods. National Fisherman, 50(8):7. (Comm. Fish. Abst. 23(2):11). Power, H. E. 1962. An improved method for the preparation of fish protein concentrate from cod. J. Fish. Res. Bd. Canada 19(6):1039. Revankar, G. D., Khabade, V. S. and Rao, S. S. V. 1965. Urea-free fish protein concentrate from shark meat. Res. Ind., New Delhi 10:364. (Fish Protein Concentrate. A Compr. Bibl., p. 25. Library of Congress, Washington, D. C. 1970). Roels, 0. A. 1969. History and present trends in FPC production. Marine Biol. Div., Lamont-Doherty, Geological Observatory of Columbia Univ., N. Y.

Simidu, W. and 0isi, K. 1952. Biochemical studies on the urea in the muscle of Elasmobranchiate fish. Mem. Coll. Agric. Kyota Univ. 62:45. (Biol. Abst. 29:25559).

Simidu, W. 1961. Non-protein nitrogenous components, In Fish as Food, p. 353. G. Borgstrom, ed. Academic Press, N. Y. 
Spinelli, J. and Koury, B. 1970. Phosphate complex of soluble fish proteins: their formation and possible uses. J. Agr. Food Chm. $18(2): 284$.

Spinel1i, J., Dyer, J., Lehman, L. and Wieg, D. 1971. The fish protein concentrate story: 13. Aqueous phosphate processing. Food Tech. $25(7): 53$.

Srikantia, S. G. and Gopalan, C. 1966. Fish protein concentrate (FPC) in the treatment of Kwashiorkor. Am. J. Clin. Nutr. 18:34. Stillings, B. R. and Knobl, G. M., Jr. 1971. Fish protein concentrate:

A new source of dietary protein. J. Am. $0 i 1$ Chem. Soc. 48(8):412. Suyama, M. and Tokuhiro, T. 1954a. Urea content and ammonia formation in the muscle of cartilagenous fishes. II. Bul1. Japan Soc. Sci. Fisheries 19:935. (Chem. Abst. 49:4190d).

Suyama, M. and Tokuhiro, T. 1954b. Note on the thermal decomposition of urea in the muscles of sharks. J. Tokyo Univ. Fisheries 41:45. (Chem. Abst. 52:20704i).

Ward, G. M., Huffman, C. F. and Duncan, C. W. 1955. Urea as protein extender for lactating cows. J. Dairy Sci. 38:298. Weast, R. C. 1969. Physical constants of organic compounds. In Handbook of Chemistry and Physics, 50th Edition. Chemical Rubber Co., Cleveland, Ohio.

West, E. S. and Todd, W. R. 1963. Textbook of Biochemistry, 3rd Ed., pp. 209, 1067 and 1300. The MacMillan Company, N. Y. Whaley, W. M. and Moshy, R. J. 1965. Fish Protein. U. S. Patent No. 3,164,471, Jan. 5, 1965. 